University of Nebraska - Lincoln

DigitalCommons@University of Nebraska - Lincoln

Paleoproterozoic high-sulfidation mineralization in the Tapajo's gold province, Amazonian Craton, Brazil: geology, mineralogy, alunite argon age, and stable-isotope constraints

\author{
Caetano Juliani \\ Instituto de Geocie nncias, Universidade de São Paulo \\ Robert O. Rye \\ U.S. Geological Survey, rrye@usgs.gov \\ Carmen M.D. Nunes \\ Instituto de Geocie ^ncias, Universidade de Sa o Paulo \\ Lawrence W. Snee \\ United States Geological Survey \\ Rafael H. Corrêa Silva \\ Instituto de Geocie^ncias, Universidade de Sa ̃o Paulo \\ See next page for additional authors \\ Follow this and additional works at: https://digitalcommons.unl.edu/usgsrye \\ Part of the Geochemistry Commons
}

Juliani, Caetano; Rye, Robert O.; Nunes, Carmen M.D.; Snee, Lawrence W.; Corrêa Silva, Rafael H.; Monteiro, Lena V.S.; Bettencourt, Jorge S.; Neumann, Rainer; and Neto, Arnaldo Alcover, "Paleoproterozoic high-sulfidation mineralization in the Tapajo's gold province, Amazonian Craton, Brazil: geology, mineralogy, alunite argon age, and stable-isotope constraints" (2005). Geochemistry of Sulfate Minerals: A Tribute to Robert O. Rye. 8.

https://digitalcommons.unl.edu/usgsrye/8

This Article is brought to you for free and open access by the US Geological Survey at DigitalCommons@University of Nebraska - Lincoln. It has been accepted for inclusion in Geochemistry of Sulfate Minerals: A Tribute to Robert O. Rye by an authorized administrator of DigitalCommons@University of Nebraska - Lincoln. 


\section{Authors}

Caetano Juliani, Robert O. Rye, Carmen M.D. Nunes, Lawrence W. Snee, Rafael H. Corrêa Silva, Lena V.S. Monteiro, Jorge S. Bettencourt, Rainer Neumann, and Arnaldo Alcover Neto 


\title{
Paleoproterozoic high-sulfidation mineralization in the Tapajós gold province, Amazonian Craton, Brazil: geology, mineralogy, alunite argon age, and stable-isotope constraints
}

\author{
Caetano Juliani ${ }^{\mathrm{a}, *}$, Robert O. Rye ${ }^{\mathrm{b}}$, Carmen M.D. Nunes ${ }^{\mathrm{a}}$, Lawrence W. Snee ${ }^{\mathrm{b}}$, \\ Rafael H. Corrêa Silva ${ }^{a}$, Lena V.S. Monteiro ${ }^{a}$, Jorge S. Bettencourt ${ }^{a}$, \\ Rainer Neumann ${ }^{\mathrm{c}}$, Arnaldo Alcover Neto ${ }^{\mathrm{c}}$ \\ anstituto de Geociências, Universidade de São Paulo, Rua do Lago, 562, CEP 05508-080, São Paulo, Brazil \\ ${ }^{\mathrm{b}}$ United States Geological Survey, Box 25046, MS 963, Denver Federal Center, Denver, Colorado 80225, USA \\ ${ }^{\mathrm{c}}$ Centro de Tecnologia Mineral, Rio de Janeiro, Rio de Janeiro, Brazil
}

Accepted 1 June 2004

\begin{abstract}
The Brazilian Tapajós gold province contains the first evidence of high-sulfidation gold mineralization in the Amazonian Craton. The mineralization appears to be in large nested calderas. The Tapajós-Parima (or Ventuari-Tapajós) geological province consists of a metamorphic, igneous, and sedimentary sequence formed during a 2.10 to $1.87 \mathrm{Ga}$ ocean-continent orogeny. The high-sulfidation mineralization with magmatic-hydrothermal alunite is related to hydrothermal breccias hosted in a rhyolitic volcanic ring complex that contains granitic stocks ranging in age from 1.89 to $1.87 \mathrm{Ga}$. Cone-shaped hydrothermal breccias, which flare upward, contain vuggy silica and have an overlying brecciated cap of massive silica; the deposits are located in the uppermost part of a ring-structure volcanic cone. Drill cores of one of the hydrothermal breccias contain alunite, natroalunite, pyrophyllite, andalusite, quartz, rutile, diaspore, woodhouseite-svanbergite, kaolinite, and pyrite along with inclusions of enargite-luzonite, chalcopyrite, bornite, and covellite. The siliceous core of this alteration center is surrounded by advanced argillic and argillic alteration zones that grade outward into large areas of propylitically altered rocks with sericitic alteration assemblages at depth. Several occurrences and generations of alunite are observed. Alunite is disseminated in the advanced argillic haloes that envelop massive and vuggy silica or that underlie the brecciated silica cap. Coarse-grained alunite also occurs in branching veins and locally is partly replaced by a later generation of fine-grained alunite. Silicified hydrothermal breccias associated with the alunite contain an estimated reserve of 30 tonnes of gold in rock that grades up to $4.5 \mathrm{~g} \mathrm{t}^{-1} \mathrm{Au}$. Seven alunite samples gave ${ }^{40} \mathrm{Ar} /{ }^{39} \mathrm{Ar}$ ages of 1.869 to $1.846 \mathrm{Ga}$, with various degrees of apparent minor Ar loss. Stable isotopic data require a magmatic-hydrothermal origin for the alunite, typical for high-sulfidation mineralization. The $\delta^{34} \mathrm{~S}$ values of most samples of alunite range from $14.0 \%$ o to $36.9 \%$. Sulfur isotopic alunite-pyrite and oxygen isotopic alunite $\mathrm{SO}_{4}-\mathrm{OH}$ temperatures range from 130 to $420{ }^{\circ} \mathrm{C}$. The $\delta \mathrm{D}_{\mathrm{H}_{2}} \mathrm{O}$ and $\delta{ }^{18} \mathrm{O}_{\mathrm{H}_{2}} \mathrm{O}$ values for alunite-forming hydrothermal fluids suggest a
\end{abstract}

* Corresponding author. Tel.: +55 113091 1642; fax: +55 1130914258.

E-mail address: cjuliani@usp.br (C. Juliani). 
predominance of magmatic water, with a small meteoric contribution. A rare sample of supergene alunite has a $\delta^{34} \mathrm{~S}$ value of $4.1 \%$ and an ${ }^{40} \mathrm{Ar}{ }^{\beta 9} \mathrm{Ar}$ age of $51.3 \pm 0.1 \mathrm{Ma}$. Other than local foliation in the volcanic rocks and recrystallization of alunite near faults, the mineralization and associated alteration appears to have been remarkably undisturbed by later metamorphism and by supergene alteration. The Au mineralization was preserved because of burial by sediments and tuffs in taphrogenic basins that probably developed shortly after mineralization and were probably first exhumed at about $60 \mathrm{Ma}$. Because high-sulfidation mineralization forms at relatively shallow crustal levels, the discoveries in Tapajós province provide new perspectives for mineral exploration for the Amazonian and perhaps for other Precambrian cratons.

(C) 2004 Elsevier B.V. All rights reserved.

Keywords: Alunite; High-sulfidation; Epithermal system; Amazonian Craton; Paleoproterozoic; Stable isotopes; Ar-Ar age; Gold mineralization; Iriri group

\section{Introduction}

High-sulfidation epithermal mineralization (Hedenquist et al., 2000) occurs in shallow crustal environments that are readily affected by weathering and rapid erosion. High-sulfidation mineral occurrences are therefore typically preserved in Tertiary-Quaternary terranes (Arribas, 1995) and rarely in Cretaceous (So et al., 1998; Nelson, 2000), Paleozoic
(Thompson et al., 1986), and Neoproterozic terranes (Dubé et al., 1998; Ayuso et al., in press). One highly metamorphosed Paleoproterozoic deposit in Sweden has been interpreted to be of the high-sulfidation type (Hallberg, 1994), but well-preserved and unmetamorphosed examples older than Neoproterozoic have not been documented previously.

Recent studies (Jacobi, 1999; Nunes et al., 2000; Juliani et al., 2000) have revealed the existence of

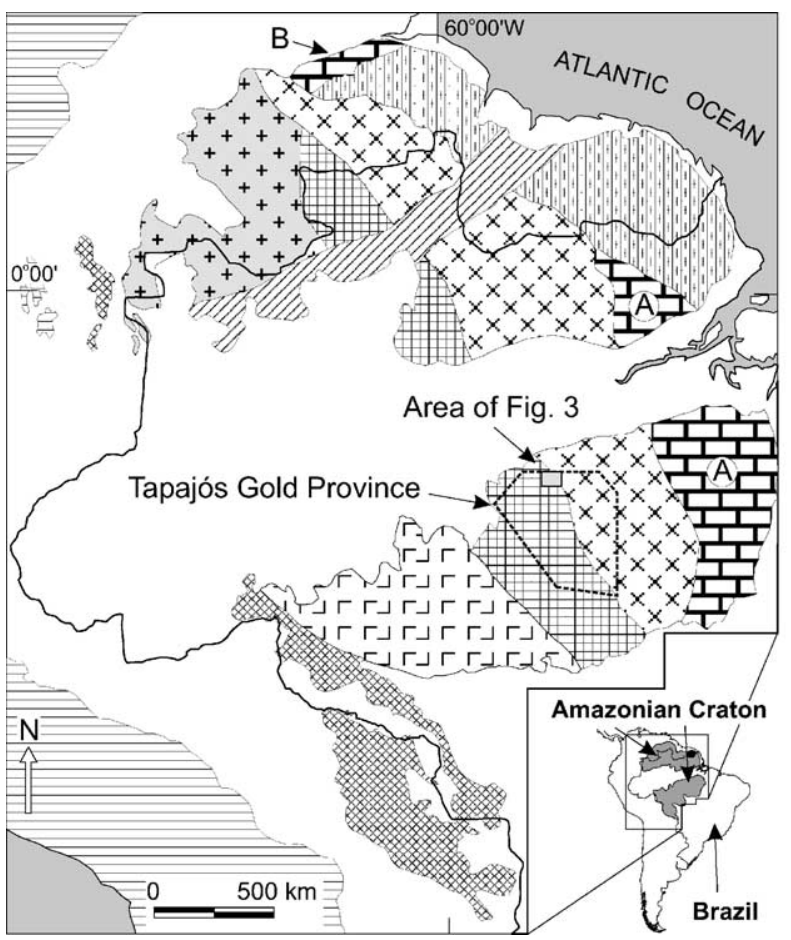

MAIN TECTONIC PROVINCES

Undifferentiated Phanerozoic sedimentary basins

Andes orogenic belt (Phanerozoic)

Sunsás (1.33-0.99 Ga)

K'Mudku (1.33-1.10 Ga)

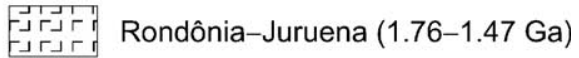

$\left[\begin{array}{l}++++ \\ ++_{+}^{+}++\end{array}\right.$Rio Negro $(1.86-1.52 \mathrm{Ga})$

\#爯 Tapás-Parima $(2.10-1.87 \mathrm{Ga})$

Transamazonic $(2.25-2.00 \mathrm{Ga})$

$\underbrace{x}_{x^{x} x^{x} x^{x}}$ Central Amazon (>2.5 Ga, 1.88-1.70 Ga magmatism)

受㿥 Carajás (A) and Imataca (B) $(3.10-2.53 \mathrm{Ga})$

Fig. 1. Location of the Tapajós gold province and the main geochronological-tectonic provinces of the Amazonian Craton, according to Santos et al. (2000). Location of Fig. 3 is outlined. 
several weakly deformed and unmetamorphosed highsulfidation mineralized systems in the Tapajós gold province (Fig. 1) related to large caldera complexes. These deposits are mineralized hydrothermal breccias in small postcaldera composite ring volcanoes and domes associated with epizonal porphyry intrusions. In one of these occurrences, hydrothermal alteration zoning is characterized by extensive silicification, pyrophyllitization, and alunitization in and around shallow hydrothermal breccias. The distal and deeper alteration zones are propylitic and sericitic.

Gold, as well as enargite-luzonite and covellite, is associated with these altered rocks. Silicified hydrothermal breccias associated with the alunite contain an estimated reserve of 30 tonnes of gold in rock that grades up to $4.5 \mathrm{~g} \mathrm{t}^{-1} \mathrm{Au}$. Occurrences such as these may have been a source for alluvial and colluvial gold deposits that, to 1997, had yielded ca. 205 tonnes (official production; Faraco et al., 1997) or more than 820 tonnes (unofficial production; Santos et al., 2001) of gold in more than 400 garimpos (small mining operations undertaken by prospectors) in the Tapajós gold province.

The Tapajós province is still undergoing exploration, and many details of the geology are not understood. The stable-isotope systematics of alunite have proved to be informative regarding the conditions associated with hydrothermal activity (Rye et al., 1992), and here, we describe the geological setting of the occurrences and the associated mineralogy, $\mathrm{Ar}$ isotopic age, and stable-isotopic geochemistry of alunite from a single high-sulfidation occurrence, the first such discovery in the Amazonian Craton. Despite the poor quality of outcrops, due to the aggressive tropical climate and dense rainforest, and the existence of few exploratory drillholes, the high-sulfidation nature of the mineralization at Tapajós can be clearly established.

\section{Geological setting}

The Tapajós gold province (Fig. 1) covers about $140,000 \mathrm{~km}^{2}$ in the Amazonian Craton (Almeida et al., 1981). A summary of major stratigraphic units and their geochronology and tectonic setting is given in Table 1 and Fig. 2. For more details, the reader is referred to papers referenced in Table 1.
The Tapajós gold province was formed shortly after the $\sim 2.10-1.87$ Ga Tapajós-Parima (Santos et al., 2000) or Ventuari-Tapajós (Tassinari and Macambira, 1999) orogenic event, which produced a welldated sequence of metamorphic, igneous, and sedimentary rocks. An oceanic-continental collisional orogeny associated with eastward shallow-dipping subduction at $\sim 1.9$ Ga resulted in the construction of the Parauari magmatic arc (Santos et al., 2000, 2001), followed by intermediate to acid volcanism of the Iriri group (Table 1) and late- to postcollisional granitic intrusions. The Iriri volcanic sequence, which is cut by epizonal granitic porphyry stocks and dikes, hosts the high-sulfidation mineral occurrences.

Mafic magmatic episodes occurred at about 1.89 , 1.78 , and $1.1 \mathrm{Ga}$, and minor lamprophyre dikes have ages ranging from 514 to 134 Ma (Table 1; Quadros et al., 1999; Almeida et al., 2000; Bahia and Quadros, 2000; Ferreira et al., 2000; Klein and Vasquez, 2000; Vasquez and Klein, 2000; Santos et al., 2001). As will be discussed, the apparent $\mathrm{Ar}$ loss exhibited by some of the alunite age spectra may have resulted from some of these younger events.

Proterozoic taphrogenic basins containing fluvial to shallow marine sequences of the Buiuçu formation overlie the volcanic rocks and coeval granites (Bezerra, 1984; Faraco et al., 1997). Paleozoic and Cenozoic sedimentary sequences covered much of the Amazonian Craton. Miocene-Pliocene and Quaternary laterization events are recognized in the southern Amazonian Craton (Faraco et al., 1997; Motta et al., 2000). Recent alluvial and colluvial deposits, commonly containing placer gold, are the youngest units in the region.

\section{Analytical methods}

Petrological, textural, and mineralogical studies utilized transmitted and reflected light optical microscopy. The mineralogy was investigated using a LEO S440 scanning electron microscope, coupled to a LINK ISIS L300 energy-dispersion microanalysis (EDS) system, with a Pentafet SiLi detector, ATW II ultrafine window, of $133 \mathrm{eV}$ to $5.9 \mathrm{keV}$ resolution and $20 \mathrm{kV}$ acceleration voltage. The backscattered electron images were acquired using a cobalt standard for 
Table 1

Main geological units and geochronology of the Tapajós gold province

\begin{tabular}{|c|c|c|c|c|c|}
\hline Geological units & Lithology & Age (Ga) & Method & Tectonic setting & References \\
\hline Phanerozoic cover & Clastic sedimentary rocks, laterite, alluvia & - & - & Intracratonic & (6) (11) \\
\hline $\begin{array}{l}\text { Cachoeira Seca } \\
\text { intrusive suite }\end{array}$ & $\begin{array}{l}\text { Subalkaline to tholeiitic olivine gabbro, } \\
\text { diorite, troctolite, diabase }\end{array}$ & $\begin{array}{l}1.192 \pm 0.012 \\
1.099 \pm 0.012\end{array}$ & $\begin{array}{l}\text { SHRIMP U-Pb } \\
\text { baddeleyite }\end{array}$ & Intracratonic & (7) (11) \\
\hline Crepori diabase & Tholeiitic augite diabase, olivine diabase & $1.778 \pm 0.009$ & $\begin{array}{l}\text { SHRIMP U-Pb } \\
\text { baddeleyite }\end{array}$ & Intracratonic & (6) (7) (11) \\
\hline Buiuçu formation & $\begin{array}{l}\text { Feldspathic sandstone, sandstone, arkose, } \\
\text { conglomerate, argillite, siltite, acid tuffs }\end{array}$ & - & - & Taphrogenic basin & $(12)$ \\
\hline \multirow[t]{2}{*}{ Maloquinha Granite } & $\begin{array}{l}\text { Subvolcanic subalkaline to alkaline } \\
\text { biotite-hornblende alkali-feldspar granite; }\end{array}$ & 1.877 to 1.864 & $\begin{array}{l}\text { SHRIMP U-Pb } \\
\text { zircon }\end{array}$ & $\begin{array}{l}\text { Postcollisional and } \\
\text { anorogenic }\end{array}$ & $(1)(2)(3)(6)$ \\
\hline & $\begin{array}{l}\text { syenogranite, monzogranite and riebeckite-arfvedsonite, } \\
\text { micromonzonite with rapakivi texture }\end{array}$ & $1.880 \pm 0.009$ & $\begin{array}{l}\mathrm{Pb}-\mathrm{Pb} \text { zircon } \\
\text { evaporation }\end{array}$ & & (9) (11) (12) \\
\hline $\begin{array}{l}\text { Moraes Almeida } \\
\text { formation }\end{array}$ & Alkaline rhyolites, ignimbrites & 1.890 to 1.875 & $\begin{array}{l}\mathrm{Pb}-\mathrm{Pb} \text { zircon } \\
\text { evaporation }\end{array}$ & $\begin{array}{l}\text { Postcollisional and } \\
\text { anorogenic }\end{array}$ & (3) \\
\hline \multicolumn{6}{|l|}{ Iriri group } \\
\hline Aruri formation & Ash flow tuff, breccia, tuffaceous sandstone & & & $\begin{array}{l}\text { Late to } \\
\text { postorogenic }\end{array}$ & $\begin{array}{l}\text { (6) (7) }(8) \\
\text { (9) }(12)\end{array}$ \\
\hline \multirow[t]{2}{*}{ Salustiano formation } & \multirow[t]{2}{*}{$\begin{array}{l}\text { Rhyolitic, rhyodacitic and dacitic volcaniclastic rocks, } \\
\text { and fayalite-hedenbergite rhyolite }\end{array}$} & $1.870 \pm 0.008$ & $\begin{array}{l}\text { SHRIMP U-Pb } \\
\text { zircon }\end{array}$ & \multirow[t]{2}{*}{$\begin{array}{l}\text { Late to } \\
\text { postorogenic }\end{array}$} & $(2)(6)(7)(8)$ \\
\hline & & $1.888 \pm 0.002$ & $\begin{array}{l}\mathrm{Pb}-\mathrm{Pb} \text { zircon } \\
\text { evaporation }\end{array}$ & & (9) (11) (12) \\
\hline $\begin{array}{l}\text { Bom Jardim } \\
\text { formation }\end{array}$ & $\begin{array}{l}\text { Andesite, dacite, trachyandesite, latite, with subordinate } \\
\text { rhyolitic and basaltic flows and volcaniclastic rocks }\end{array}$ & $\begin{array}{l}1.893 \pm 0.005 \\
1.888 \pm 0.007\end{array}$ & $\begin{array}{l}\mathrm{Pb}-\mathrm{Pb} \text { zircon } \\
\text { evaporation }\end{array}$ & $\begin{array}{l}\text { Late- to } \\
\text { postorogenic }\end{array}$ & (6) (7) \\
\hline \multirow[t]{2}{*}{$\begin{array}{l}\text { Rosa de Maio and } \\
\text { Batalha granites }\end{array}$} & \multirow[t]{2}{*}{ Calc-alkaline hornblende-biotite and biotite granites } & $1.883 \pm 0.004$ & $\begin{array}{l}\text { SHRIMP U-Pb } \\
\text { zircon }\end{array}$ & \multirow[t]{2}{*}{$\begin{array}{l}\text { Late- to post-Parauari } \\
\text { magmatic arc (II) }\end{array}$} & \multirow[t]{2}{*}{ (10) (13) } \\
\hline & & $1.879 \pm 0.011$ & U-Pb zircon & & \\
\hline
\end{tabular}


Ingarana intrusive suite

Parauari intrusive suite

Abacaxis and Sequeiro formations

Creporizão intrusive suite

Vila Riozinho formation

Cuiú-Cuiú complex

Jacareacanga group
Subalkaline olivine gabbro, augite gabbro, norite, anorthosite, ferrosilite diabase

Porphyritic hornblende-biotite monzogranite, granodiorite, syenogranite, tonalite

Pinkish siltstone, sandstone, claystone; quartz wackes

Metamorphosed porphyritic syeno- and monzogranites, granodiorite, tonalite

Calc-alkaline to shoshonitic basaltic andesite, basaltic trachyandesite, trachyte, rhyolite

Granodioritic to tonalitic gneisses, migmatite, amphibolite enclaves

Phyllite, schist, metaturbidite, quartzite, metabasite, BIF (low to medium metamorphic grade)

$\begin{array}{lll}1.879 \text { to } 1.873 & \begin{array}{l}\text { SHRIMP U-Pb } \\ \text { zircon }\end{array} & \begin{array}{l}\text { Parauari arc } \\ \text { basic magmatism }\end{array} \\ 1.887 \pm 0.003 & \begin{array}{l}\mathrm{Pb}-\mathrm{Pb} \text { zircon } \\ 1.898 \text { to } 1.880\end{array} & \begin{array}{l}\text { SHRIMP U-Pb } \\ \text { zircon }\end{array} \\ \begin{array}{l}\mathrm{Pb}-\mathrm{Pb} \text { zircon } \\ 1.883 \pm 0.002\end{array} & \begin{array}{l}\text { Calc-alkaline } \\ \text { magmatic } \\ \text { arc (II) }\end{array}\end{array}$

(4) (7) (11)

1.900 to 1.895

$\mathrm{U}-\mathrm{Pb}$ zircon

1.974 to 1.957

SHRIMP U-Pb

zircon

$1.968 \pm 0.019$

$\mathrm{Pb}-\mathrm{Pb}$ zircon

$2.000 \pm 0.004$

$1.998 \pm 0.003$

evaporation

$\mathrm{Pb}-\mathrm{Pb}$ zircon

evaporation

2.033 to 2.005

\section{SHRIMP U-Pb}

zircon

2.125 to 2.098
Parauari foreand back-arc (II)

basins

$\operatorname{arc}(\mathrm{I})$

Calc-alkaline

magmatic

$\operatorname{arc}(\mathrm{I})$

magmatic

$\operatorname{arc~(I)~}$

Trench basin
Late-magmatic
(5) (6) (7) (8)

(9) (10)

(11) (12)

(6) (10) (11)

(5) (9) (11) (12)

(6) (7) (8) (9)

(11) (12)

(6) (8) (10)

References: (1) Dall'Agnol et al. (1994), (2) Dall’Agnol et al. (1999), (3) Lamarão et al. (2002), (4) Quadros et al. (1999), (5) Ricci et al. (1999), (6) Almeida et al. (2000), (7) Bahia and Quadros (2000), (8) Ferreira et al. (2000), (9) Klein and Vasquez (2000), (10) Santos et al. (2000), (11) Santos et al. (2001), (12) Vasquez and Klein (2000), (13) Juliani et al. (2002).

${ }^{a}$ Age of intermediate-composition volcanic rocks of the base of the Iriri group. The rocks from the type locality of the Bom Jardim formation were not dated. 


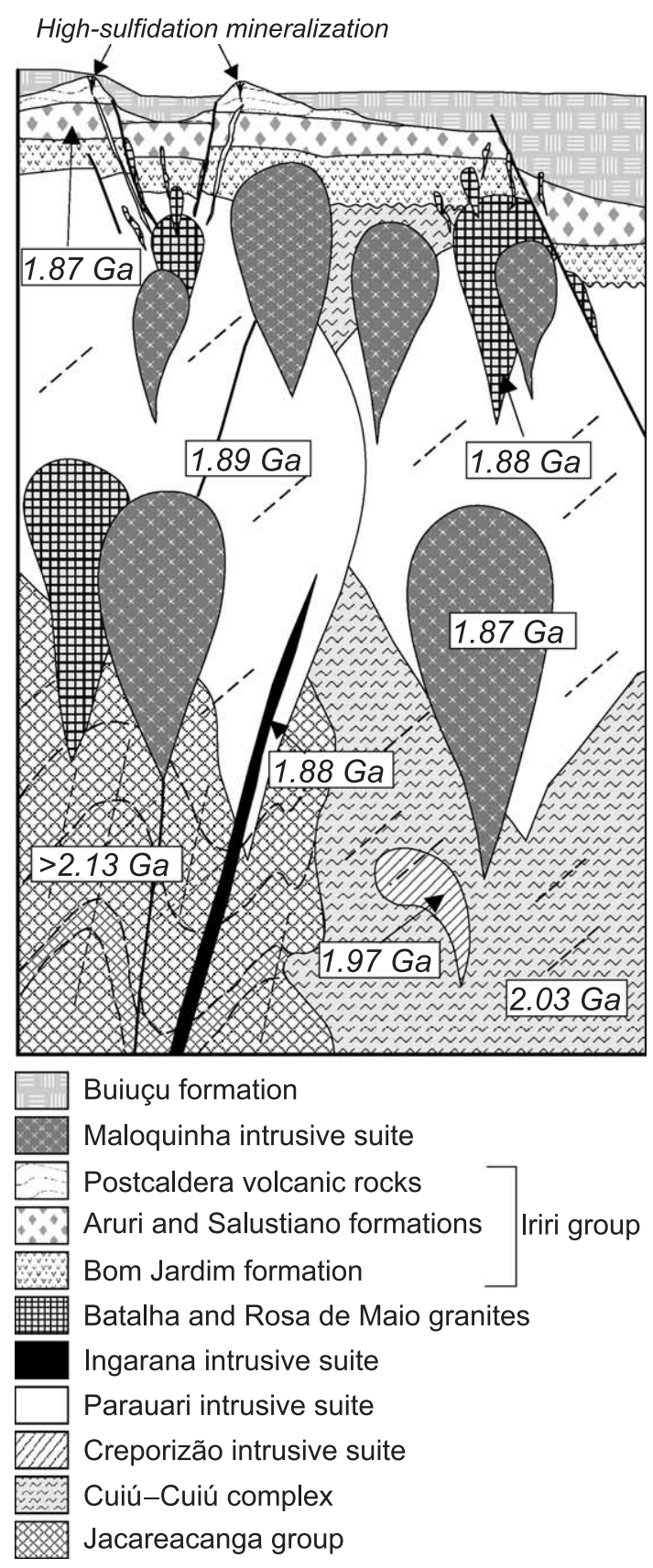

Fig. 2. Schematic stratigraphic column of the main units of the Tapajós gold province (modified from Juliani et al., 2000).

calibration of the semiquantitative EDS analyses. Analyses of alunite were obtained with JEOL JXA 8600 and CAMECA SX50 electron microprobes, using 5 and $20 \mathrm{nA}$ as sample current, $15 \mathrm{kV}$ as accelerating voltage, and a beam diameter of 10 to 20 $\mu \mathrm{m}$. The electron microprobe data for alunite are given in Table 2. X-ray diffraction (XRD) identifications were made using a SIEMENS D-5000 diffractometer and $\mathrm{Cu} \mathrm{X}$-radiation. The hydrothermal alteration minerals in drill-core samples were also identified using an Integrated Spectronics G8630 PIMA (Portable Infrared Mineral Analyzer).

Alunite from surface and drill-core samples was dated by the ${ }^{40} \mathrm{Ar} /{ }^{39} \mathrm{Ar}$ incremental heating method following procedures outlined by Snee (2002). The alunite samples are both coarse- and fine-grained, and some have minor $(<1 \%)$ inclusions of fine-grained pyrite, which was not removed. Eight to $12 \mathrm{mg}$ of each alunite sample were irradiated in quartz vials for 30 to $129 \mathrm{~h}$ at $1 \mathrm{MW}$ in the central thimble of the U.S. Geological Survey research reactor. Three of the alunite samples were irradiated in vacuum-evacuated capsules to capture potentially recoiled Ar isotopes. Neutron flux during irradiation was monitored by hornblende standard MMhb-1, which has a $\mathrm{K}-\mathrm{Ar}$ age of $523.1 \pm 1.7 \mathrm{Ma}$ (Renne et al., 1998). After irradiation, the evacuated quartz vials were opened under vacuum, and the contents of the vial were analyzed to determine whether any Ar had been released from the sample during irradiation. No ${ }^{40} \mathrm{Ar}$ and 1 part in $500{ }^{39} \mathrm{Ar}$, even for fine-grained $(\sim 10-\mu \mathrm{m}$ diameter) samples, were lost into the vacuum during irradiation. Subsequently, the samples were progressively degassed in a double-vacuum resistance furnace in a series of 8 to 17 heating steps, each $30 \mathrm{~min}$ long, to a maximum of $1350{ }^{\circ} \mathrm{C}$; the majority of the Ar was released between 550 and $725^{\circ} \mathrm{C}$, although one sample released its Ar between 700 and $950{ }^{\circ} \mathrm{C}$. Apparent ages for each step were calculated using the decay constants of Steiger and Jäger (1977). The Ar data and detailed analytical procedures are given in Appendix A.

For stable-isotope analyses of alunite and pyrite, pure separates were obtained by hand picking. The $\delta{ }^{34} \mathrm{~S}$ and $\delta{ }^{18} \mathrm{O}$ values of alunite $\mathrm{SO}_{4}$ and the $\delta \mathrm{D}$ and $\delta^{18} \mathrm{O}$ values of alunite $\mathrm{OH}$ were determined using the sample preparation techniques described by Wasserman et al. (1992) and conventional mass-spectrometer analyses. The sulfur isotopic composition of alunite and pyrite was analyzed using continuous-flow techniques. Stable-isotope data are reported in the $\delta$ - 
Table 2

Representative electron microprobe compositions of alunite

\begin{tabular}{|c|c|c|c|c|c|c|c|c|c|c|c|c|c|c|}
\hline \multirow{3}{*}{$\begin{array}{l}\text { Sample type wt.\% } \\
\mathrm{K}_{2} \mathrm{O}\end{array}$} & \multicolumn{4}{|c|}{$X 1-16-9$} & \multicolumn{7}{|c|}{ X1-16-19 } & \multicolumn{3}{|c|}{ FV3-1-16 } \\
\hline & \multicolumn{2}{|l|}{$\mathrm{A}_{3}$} & \multicolumn{2}{|l|}{$\mathrm{A}_{5}$} & \multicolumn{3}{|l|}{$\mathrm{A}_{3}$} & \multicolumn{2}{|l|}{$\mathrm{A}_{4}$} & \multicolumn{2}{|l|}{$\mathrm{A}_{5}$} & \multicolumn{3}{|l|}{$\mathrm{B}_{1}$} \\
\hline & 9.61 & 9.99 & 9.01 & 10.07 & 6.33 & 7.48 & 7.82 & 8.37 & 9.94 & 6.87 & 7.28 & 3.91 & 6.04 & 6.25 \\
\hline $\mathrm{Na}_{2} \mathrm{O}$ & 0.92 & 0.61 & 1.17 & 0.50 & 2.90 & 2.10 & 2.11 & 1.40 & 0.38 & 2.38 & 2.02 & 4.86 & 3.46 & 3.30 \\
\hline $\mathrm{CaO}$ & 0.02 & 0.01 & 0.02 & 0.02 & 0.07 & 0.06 & 0.02 & 0.03 & n.d. & 0.05 & 0.03 & 0.09 & 0.12 & 0.10 \\
\hline $\mathrm{SrO}$ & 0.24 & 0.17 & 0.24 & 0.33 & 0.11 & 0.05 & 0.12 & 0.11 & 0.06 & 0.27 & 0.12 & n.d. & 0.10 & 0.07 \\
\hline $\mathrm{BaO}$ & 0.08 & 0.50 & 0.28 & 0.00 & 0.16 & 0.11 & 0.03 & 0.16 & 0.31 & 0.07 & 0.05 & n.d. & n.d. & 0.10 \\
\hline $\mathrm{Al}_{2} \mathrm{O}_{3}$ & 37.37 & 35.97 & 36.73 & 36.89 & 36.62 & 36.72 & 36.81 & 35.81 & 36.16 & 36.68 & 36.30 & 37.68 & 37.14 & 37.48 \\
\hline $\mathrm{Fe}_{2} \mathrm{O}_{3}$ & 0.09 & 0.08 & 0.18 & 0.01 & n.d. & n.d. & 0.06 & n.d. & n.d. & n.d. & n.d. & 0.02 & 0.12 & 0.10 \\
\hline $\mathrm{SO}_{3}$ & 38.10 & 37.77 & 37.67 & 38.31 & 38.07 & 37.89 & 38.34 & 38.00 & 37.84 & 38.30 & 37.16 & 38.60 & 38.37 & 38.42 \\
\hline $\mathrm{P}_{2} \mathrm{O}_{5}$ & 0.19 & 0.35 & 0.32 & 0.51 & 0.11 & 0.14 & 0.01 & 0.10 & 0.01 & 0.14 & 0.08 & 0.06 & 0.25 & 0.16 \\
\hline $\mathrm{SiO}_{2}$ & n.d. & n.d. & n.d. & n.d. & n.d. & 0.02 & 0.01 & 0.03 & n.d. & n.d & 0.39 & 0.09 & 0.12 & 0.01 \\
\hline Total & 86.62 & 85.45 & 85.62 & 86.64 & 84.37 & 84.58 & 85.33 & 84.01 & 84.70 & 84.76 & 83.43 & 85.31 & 85.72 & 85.99 \\
\hline \multicolumn{15}{|c|}{ formula contents for $\mathrm{XO}_{4}=2$} \\
\hline $\mathrm{K}$ & 0.853 & 0.890 & 0.806 & 0.881 & 0.564 & 0.668 & 0.693 & 0.746 & 0.893 & 0.607 & 0.655 & 0.343 & 0.529 & 0.550 \\
\hline $\mathrm{Na}$ & 0.124 & 0.083 & 0.159 & 0.066 & 0.392 & 0.285 & 0.284 & 0.190 & 0.052 & 0.320 & 0.276 & 0.648 & 0.461 & 0.442 \\
\hline $\mathrm{Ca}$ & 0.001 & 0.001 & 0.002 & 0.001 & 0.005 & 0.004 & 0.001 & 0.002 & 0.000 & 0.004 & 0.002 & 0.007 & 0.009 & 0.007 \\
\hline $\mathrm{Sr}$ & 0.010 & 0.007 & 0.010 & 0.013 & 0.004 & 0.002 & 0.005 & 0.004 & 0.002 & 0.011 & 0.005 & 0.000 & 0.004 & 0.003 \\
\hline $\mathrm{Ba}$ & 0.002 & 0.014 & 0.008 & 0.000 & 0.004 & 0.003 & 0.001 & 0.004 & 0.009 & 0.002 & 0.001 & 0.000 & 0.000 & 0.003 \\
\hline $\mathrm{Al}$ & 3.064 & 2.960 & 3.034 & 2.980 & 3.012 & 3.029 & 3.014 & 2.948 & 3.001 & 2.996 & 3.019 & 3.051 & 3.006 & 3.049 \\
\hline $\mathrm{Fe}$ & 0.005 & 0.004 & 0.009 & 0.001 & 0.000 & 0.000 & 0.003 & 0.000 & 0.000 & 0.000 & 0.000 & 0.001 & 0.006 & 0.005 \\
\hline $\mathrm{S}$ & 1.989 & 1.979 & 1.981 & 1.970 & 1.994 & 1.991 & 1.998 & 1.992 & 1.999 & 1.992 & 1.968 & 1.991 & 1.977 & 1.990 \\
\hline $\mathrm{P}$ & 0.011 & 0.021 & 0.019 & 0.030 & 0.006 & 0.008 & 0.001 & 0.006 & 0.001 & 0.008 & 0.005 & 0.003 & 0.015 & 0.009 \\
\hline $\mathrm{Si}$ & 0.000 & 0.000 & 0.000 & 0.000 & 0.000 & 0.001 & 0.001 & 0.002 & 0.000 & 0.000 & 0.027 & 0.006 & 0.008 & 0.001 \\
\hline Total & 6.059 & 5.959 & 6.028 & 5.942 & 5.981 & 5.991 & 6.001 & 5.895 & 5.957 & 5.940 & 5.958 & 6.050 & 6.015 & 6.059 \\
\hline
\end{tabular}

n.d.-not detected.

notation, as permil, relative to Cañon Diablo Troilite (CDT) for sulfur, and Standard Mean Ocean Water (SMOW) for oxygen and hydrogen. Analytical uncertainty $(2 \sigma)$ is $\pm 0.2 \%$ for sulfur and oxygen, and $\pm 3 \%$ for hydrogen.

\section{Results and analyses}

\subsection{Regional geological structures}

The regional geological structures were identified with TM-LANDSAT 5 digital images and aerial RADAMBRASIL Project radar images. Regional geological structures identified from remote-sensing images within the Tapajós gold province are shown in Fig. 3. In this figure, large circular structures are identified and, with supporting geological studies, are interpreted to be nested and overlapping calderas up to $20 \mathrm{~km}$ in diameter. Some of the calderas have smaller circular structures that are related to small, dacitic to rhyodacitic epizonal porphyry stocks. Other features are interpreted to be intracaldera resurgent domes or small composite volcanoes. Several semieroded postcollapse rhyolitic volcanic vents or domes are present along ring structures of some of the large calderas (Fig. 3). Circular structures representing epizonal stocks are also common in the caldera ring-structure complexes. The geological map of the rectangular area in Fig. 3 is shown in Fig. 4.

\subsection{Geological setting of the high-sulfidation mineralization}

Three main volcanic-related sequences of the Iriri group (Bom Jardim, Salustiano, and Aruri formations) and a postcaldera volcanic unit, identified in this study, overlie the syntectonic magmatic arc-related Parauari granites (Table 1; Figs. 3 and 4). The volcanic stratigraphy of the Tapajós gold province is not well established, and the correlation of these units with caldera evolution is only beginning (Juliani et al., 


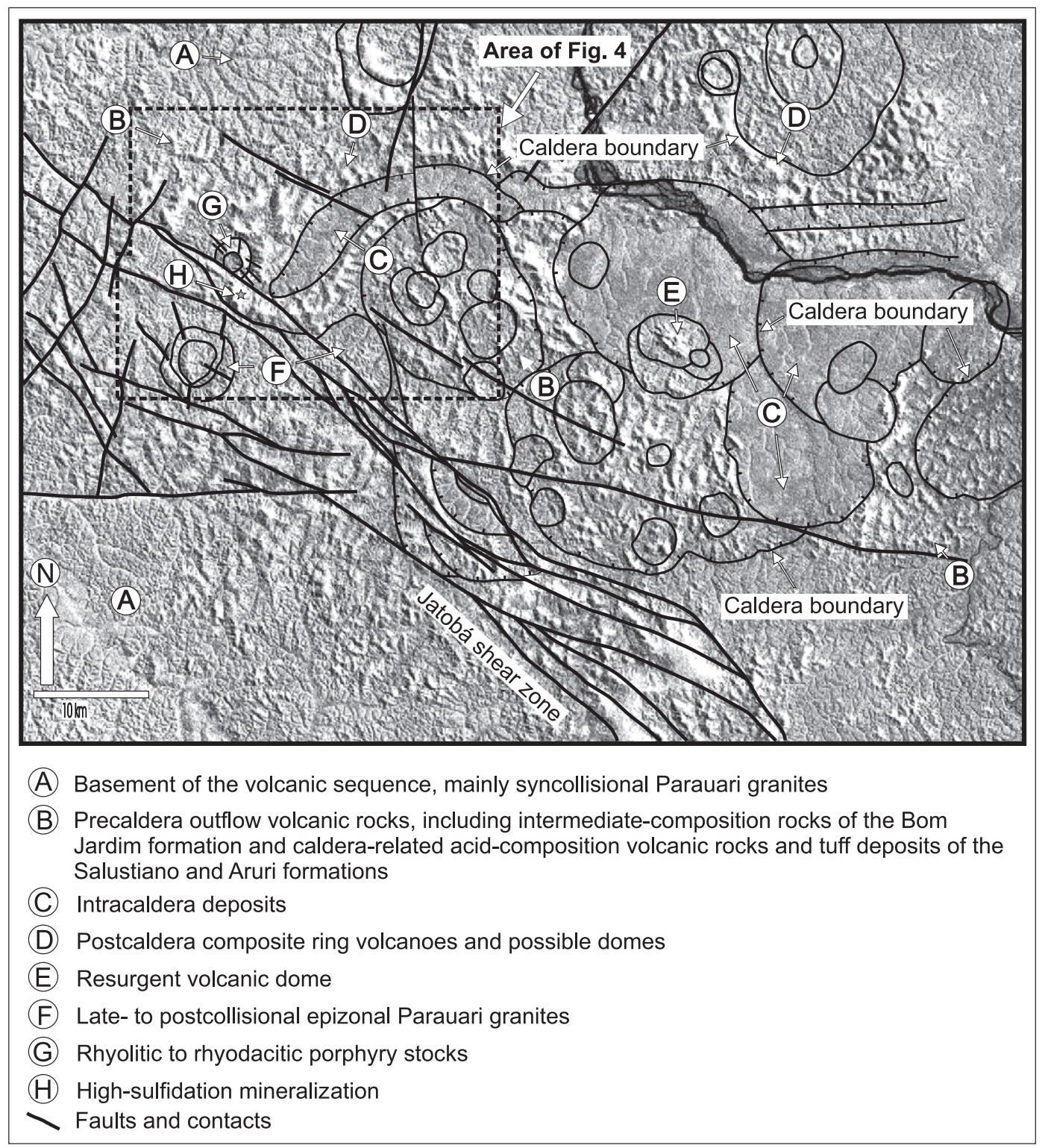

Fig. 3. PC1, TM-LANDSAT image with interpreted ring structures associated with the collapse of ash flow calderas and crosscutting circular granite, granophyre, and porphyry intrusions. The interpretations are based on observations of rocks during geological mapping. The dashed rectangle at the upper left delimits the area of Fig. 4.

2000, 2003). Results to date indicate that the lower unit (Bom Jardim formation) is composed mainly of precaldera andesitic and dacitic flow and tuff deposits. The middle unit includes the Salustiano and Aruri formations, which consist of ash flow tuffs, rhyolitic flows, and rhyolitic epiclastic volcanics associated with the caldera formation. Postcaldera volcanism is represented by small rhyolitic composite ring volcanoes with radiating lava flows and welded tuffs, and by domes (Figs. 3 and 4), which host high-sulfidation epithermal mineral occurrences. Intracaldera deposits are silicified ash flow tuffs, epiclastic tuffs, arenites, 


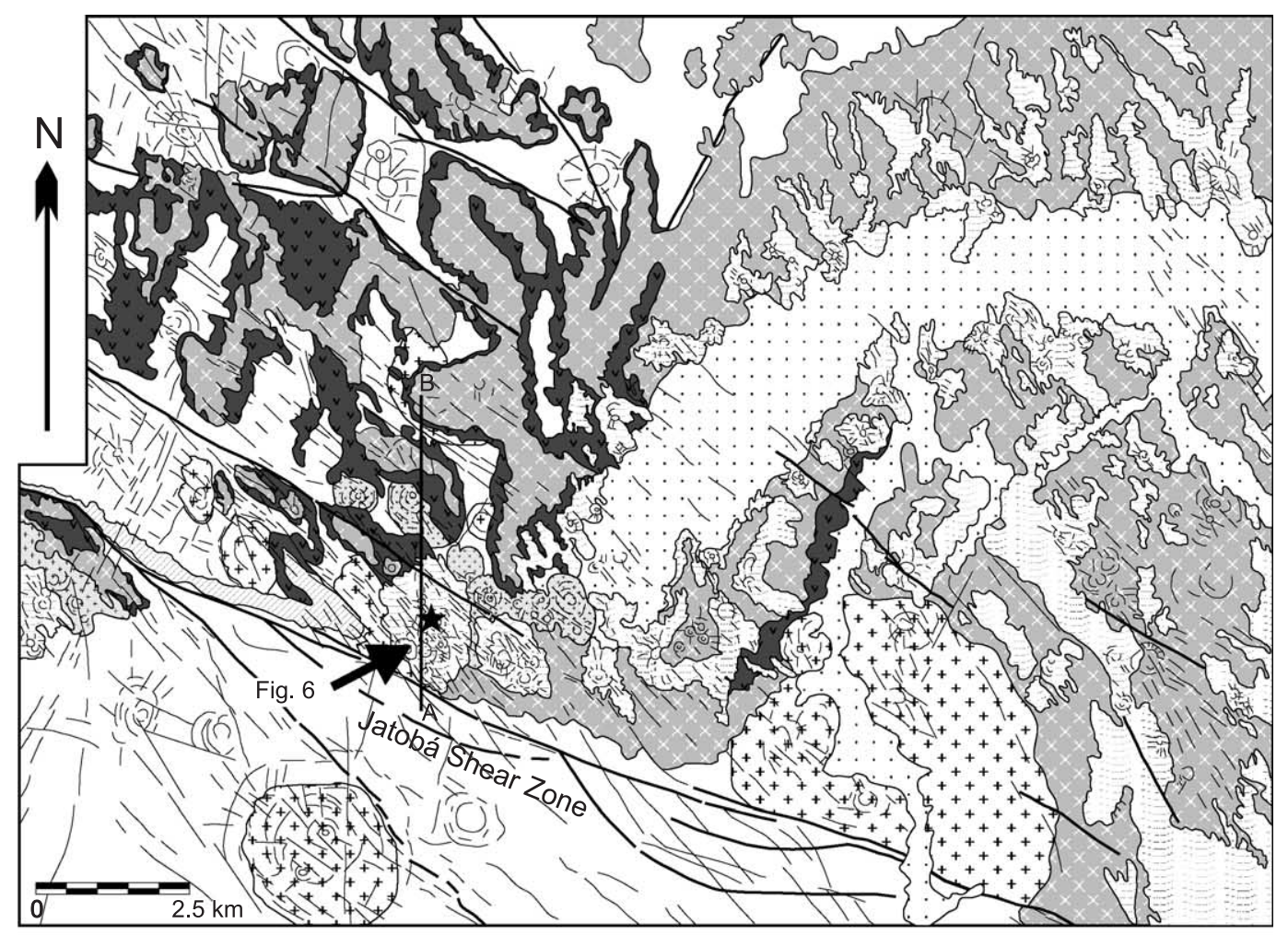

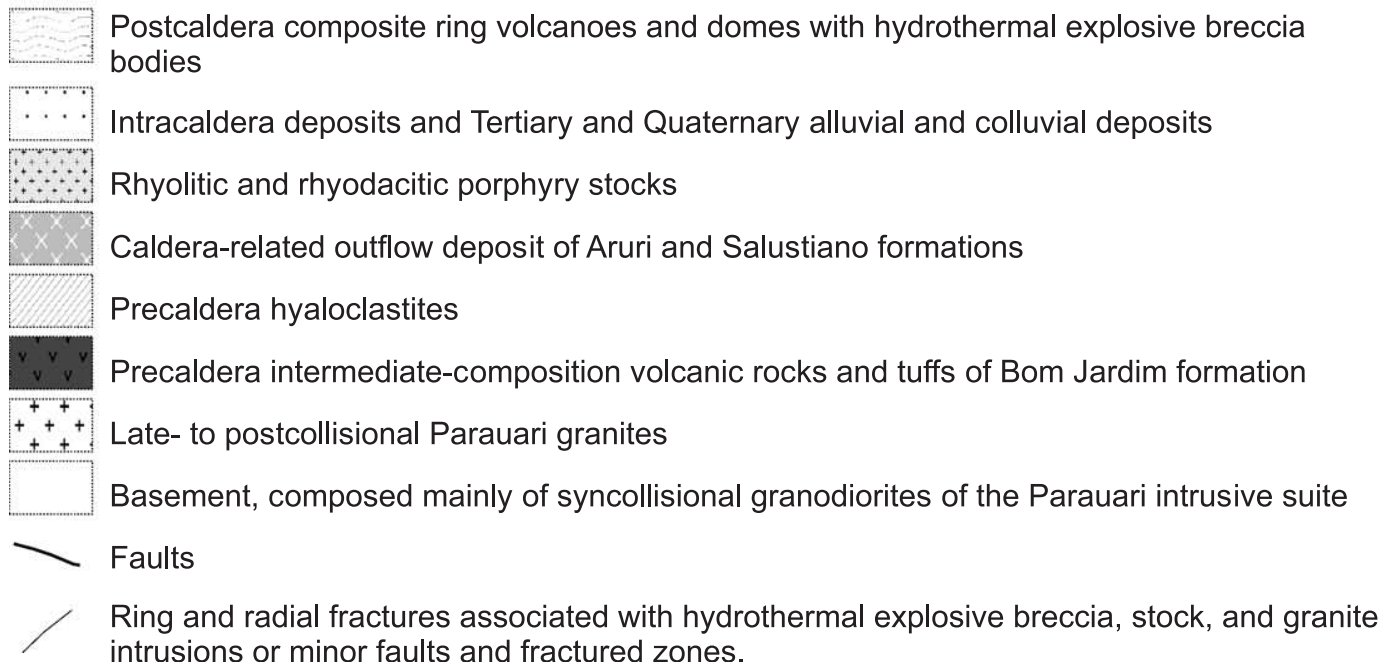

Fig. 4. Geological map of the exploration area. (A)-(B) is the line of cross-section shown in Fig. 5. The arrow indicates the volcanic structure with high-sulfidation mineralization shown in Fig. 6, and the black star shows the location of the high-sulfidation gold deposit.

and mudstones. Granophyric dacitic to rhyolitic epizonal stocks and dikes crosscut the volcanosedimentary sequence.
A diagrammatic cross-section essential to understanding the geological framework of a typical highsulfidation mineral occurrence in the Tapajós gold 
province is shown in Fig. 5, which includes the location of some colluvial and placer gold deposits. The important units in this cross-section are discussed below.

\subsubsection{Basement}

The basement for the volcanic and volcaniclastic rocks of the Iriri group is well exposed at the southern part of the Jatobá shear zone (Figs. 3 and 4 ), where the supracrustal rocks are almost completely eroded. The basement is represented by syncollisional calc-alkaline batholithic granitic bodies of the $\sim 1.9$ Ga Parauari intrusive suite (Santos et al., 2000, 2001). Light pink to gray biotite- and hornblende-bearing foliated granodiorite predomi- nates, with subordinate monzogranite and tonalite. These rocks are medium- to fine-grained, equigranular to porphyritic, and are intruded by aplite, diabase, and gabbroic dikes.

\subsubsection{Precaldera volcanism}

Precaldera volcanism is represented by the Bom Jardim formation $(\sim 1.89 \mathrm{Ga}$; Table 1$)$, which overlies the granitic basement, and consists predominantly of calc-alkaline andesite and dacite, commonly porphyritic, and volcaniclastic rocks. Rhyolitic lavas and tuffs, amygdaloidal basalt, and trachyte flows are also present. Basaltic or andesitic intrusive hydrothermal breccias occur locally. This formation appears to represent the eroded remains of precollapse clustered

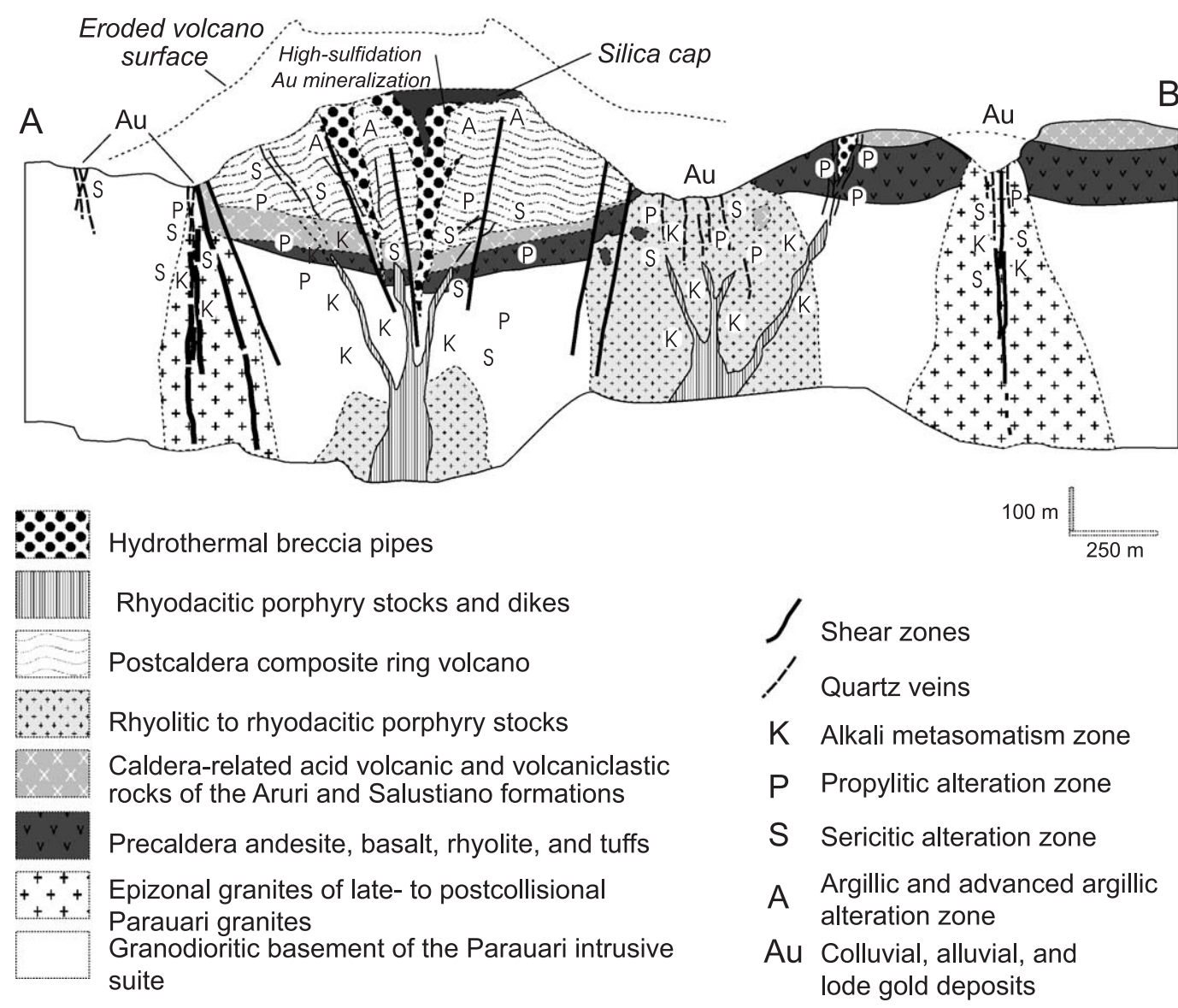

Fig. 5. Interpreted geological cross-section along (A)-(B) of Fig. 4, showing the location of the high-sulfidation gold mineralization and of garimpos (small mining operations in colluvial and alluvial deposits undertaken by prospectors). 
stratovolcanoes associated with back-arc rifts related to the Parauari subduction.

\subsubsection{Caldera-related volcanism}

The caldera-forming deposits are represented by large intracaldera and outflow sheets of ash flow tuffs and acid volcanic rocks of the Salustiano and Aruri formations (1.89-1.87 Ga; Table 1), which overly the Bom Jardim formation. The volcaniclastic rocks are composed of rhyolitic ash flow tuffs, crystal tuffs, welded tuffs, lapilli stones, and volcanic agglomerates, with minor dacitic ash flow tuffs. The rhyolites have an aphanitic or vitreous matrix and, commonly, amygdules and flow structures. Flows of hyaloclastite and epiclastic volcanic rocks are also present.

\subsubsection{Intracaldera deposits}

The basal intracaldera deposits are composed mainly of ash flow tuffs, volcanic flow breccias and agglomerates, and minor rhyolite flows, hyaloclastites, epiclastic tuffs, arkoses, and arenites. This sequence grades upward into feldspathic and lithic sandstones with abundant beds of arkose and siltstone, and with minor conglomerate, sedimentary breccia, and mudstone. Chert and carbonaceous- and sulfiderich layers are locally present. The sedimentary structures and lithotypes indicate a depositional environment in part related to alluvial and lacustrine settings.

\subsubsection{Postcaldera volcanism}

The postcaldera volcanic units, which host the high-sulfidation mineral occurrences, occur as vents along rings (Fig. 4) and within calderas (Fig. 3). Few of these volcanic structures were studied, and the rocks are poorly exposed, which makes it difficult to classify them. A few exploration drillholes in one of these volcanic ring structures showed interbedded acid- and intermediate-composition flows, and welded tuffs, which indicate a similarity to composite volcanoes. However, the landforms of other of these structures are similar to those of ring and intracaldera resurgent domes.

The volcanic sequence contains, at the base, discontinuous massive or banded fine-grained dacite and dacitic tuff flows. These rocks are overlain by layered rhyolitic tuffs, rhyolitic to dacitic lapilli tuffs, lapilli stones, welded tuffs, ash flow tuffs, and pyroclastic breccias. Ellipsoidal dacite bombs with trachytic textures were observed in the rhyolitic tuff pile. Annular and radial fractures are associated with upward-flaring cone-shaped bodies of hydrothermal breccias that have an intensely flow-oriented matrix and rounded fragments. The tuffs close to the hydrothermal breccias have been hydraulically fractured. On top of the semieroded volcanic cones, the explosive hydrothermal breccia bodies are covered by a massive hematite-rich and vuggy silica cap, which is cut by explosive breccias. The inner breccia bodies contain intensely silicified rocks and massive and vuggy silica.

\subsubsection{Granitic plutons and granophyric stocks}

Massive, hololeucocratic to leucocratic, coarsegrained, porphyritic hornblende-biotite monzogranite stocks, and dikes crosscut the basement (Fig. 4) and intrude the Bom Jardim and Salustiano formations, but do not cut the upper volcanic rocks. These granitic rocks are coeval with caldera-related volcanism and are correlated with the late-orogenic Parauari magmatism, similar to the $\sim 1.88 \mathrm{Ga}$ Batalha and Rosa de Maio granites (Table 1; Santos et al., 2000, 2001; Juliani et al., 2002). These granitic rocks have granophyric textures, indicating shallow emplacement. Rhyolitic to rhyodacitic epizonal granophyric stocks related to hydrothermal systems crosscut the volcanics, tuffs, intracaldera sedimentary rocks, and the monzogranites. Some of the granophyres exhibit strong fragmental features and a flow-oriented matrix, suggesting a genetic relationship with the explosive hydrothermal breccias of ring volcanic cones.

\subsubsection{Late porphyry dikes}

Meter-thick dikes of fine-grained rhyodacitic porphyry crosscut all volcanic units. The dikes are related to high-sulfidation mineralization in ring vents and have a dark red color mainly attributable to potassic alteration. These hypabyssal intrusions probably are emplaced mainly along ring and radial structures of the calderas.

\subsection{Hydrothermal alteration}

A brecciated siliceous zone interpreted to be a silica cap was initially recognized from surface 


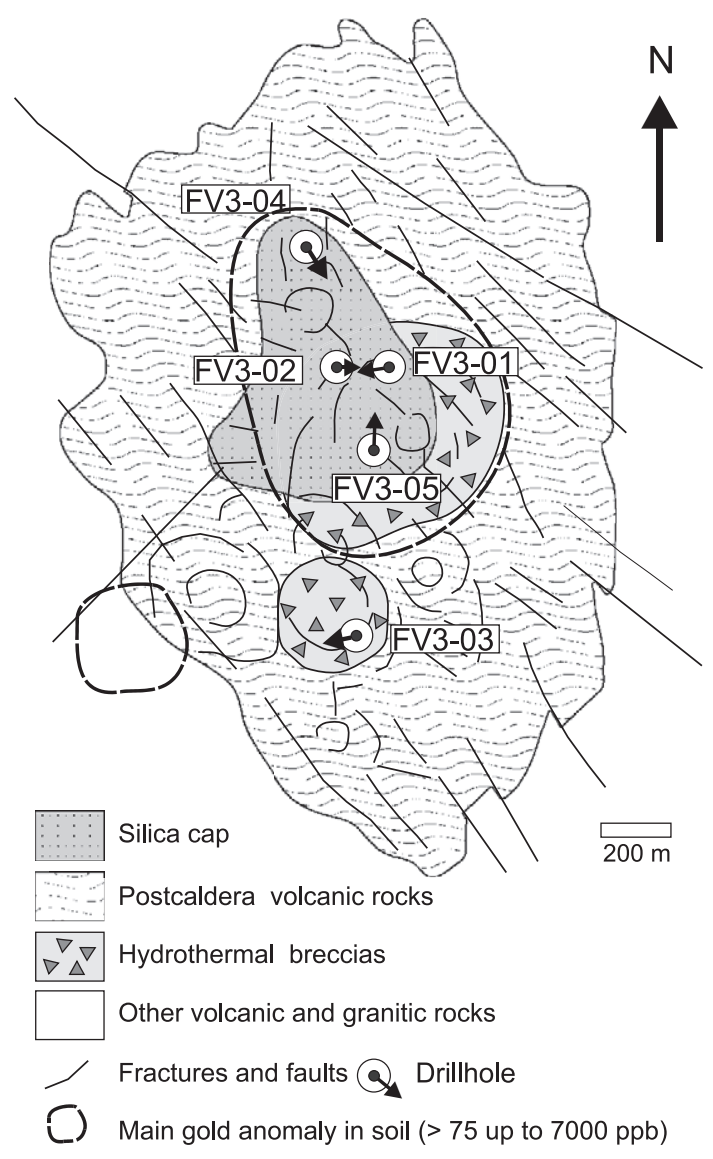

Fig. 6. Geological map of one of the Tapajós high-sulfidation occurrences, showing the location of drillholes. exposures of the hydrothermal breccias. Studies of samples from trenches and five holes (Fig. 6) drilled in and near the siliceous cap permitted three-dimensional reconstruction of the siliceous and related alteration as shown diagrammatically in Fig. 7.

\subsubsection{Silicification and hematitization}

The silica cap overlying the hydrothermal breccia on a ring volcano contains vuggy (Fig. $8 \mathrm{a}$ ), massive to layered bodies of siliceous rock formed by acid leaching and silicification of breccias and ash flow tuffs. At depth, the inner alteration zones consist of massive and vuggy silica enclosed in a quartz-alunite zone closely associated with the hydrothermal breccias at shallow levels of the volcanic structure. Commonly, vugs have druse relicts and are filled by quartz containing very small aqueous fluid inclusions. These siliceous rocks consist of microcrystalline quartz and contain hematite \pm pyrophyllite \pm alunite \pm sulfides and relict feldspar crystals. Hematite occurs only near the surface, where it replaced sulfides and infilled fractures. The silica cap is cut by silicified hydrothermal explosion breccias with fragments of tuff, silicified rhyolite, red 'chalcedony', and siliceous rock cemented by microcrystalline quartz and finegrained hematite. Centimeter-thick irregular veins of milky quartz with subordinate pyrophyllite cut the silica cap.

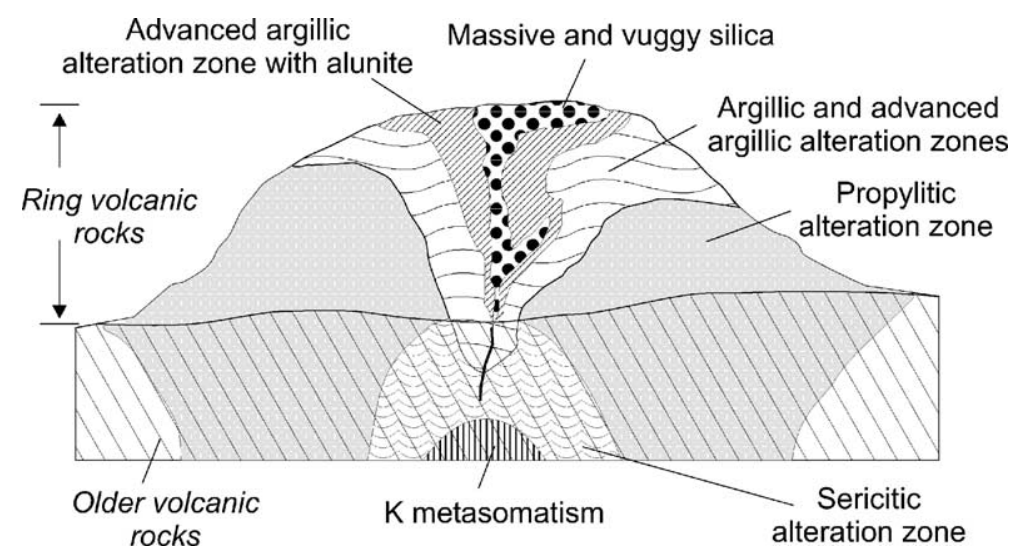

Fig. 7. Schematic reconstruction, based on studies of surface and drillhole samples, of the alteration zones of a typical Tapajós high-sulfidation mineral occurrence in ring-structure volcanic rocks. 

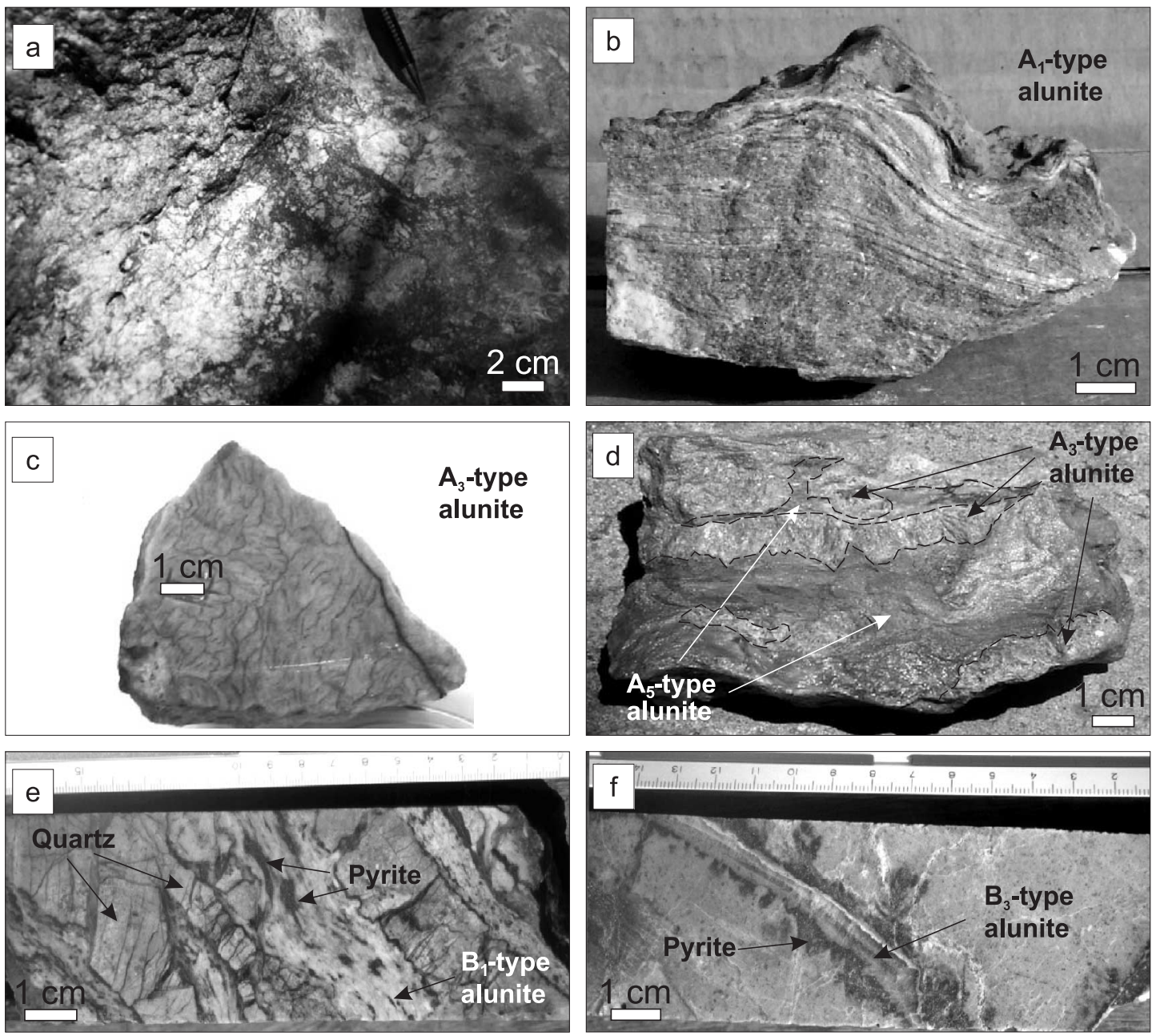

Fig. 8. Macroscopic features of the silica cap and alunite types from shallow and deep zones: (a) hematite-rich siliceous rock from the silica cap; (b) $\mathrm{A}_{1}$-type fine-grained, strongly foliated alunite; (c) $\mathrm{A}_{3}$-type coarse-grained branching alunite from veins (dark lines show the crystal outlines); (d) $\mathrm{A}_{3}$-type coarse-grained alunite replaced by $\mathrm{A}_{5}$-type fine-grained foliated alunite (dashed lines show the outlines of coarse-grained alunite crystals); (e, f) macroscopic features of the alunite types from deeper zones: (e) $B_{1}$-type fine-grained, foliated alunite associated with pyrite that envelopes microcrystalline quartz; (f) $\mathrm{B}_{3}$-type coarse-grained alunite veins that replace fissure-controlled pyrite-rich zones.

\subsubsection{Advanced argillic alteration with quartz and alunite}

Quartz-alunite alteration assemblages have a strong correlation to hydrothermal breccia bodies, are concentrated mainly under the silica cap, and form an envelope around the massive and vuggy silica. Near the siliceous zones, welded tuffs were strongly alunitized and cut by coarse-grained alunite veins. Alunite decreases progressively away from the hydrothermal breccias, as pyrophyllite increases, until alunite disappears approximately $200 \mathrm{~m}$ from the breccias. The alunitized zones also decrease with increasing depth, although alunite was identified down to $230 \mathrm{~m}$. In the shallowest alunite occurrences, under the silica cap, five varieties of alunite are identified: $\left(A_{1}\right)$ red to pinkish colored, fine-grained, strongly oriented alunite, which completely replaced the preexisting rock (Fig. $8 \mathrm{~b}) ;\left(\mathrm{A}_{2}\right)$ red coarse-grained alunite from deformed veins; $\left(A_{3}\right)$ pinkish, rose, or red undeformed alunite with branching crystals up to $4 \mathrm{~cm}$ 
long that grew toward the vein center (Fig. 8c,d); $\left(\mathrm{A}_{4}\right)$ rose or red, medium- to fine-grained, randomly orientated alunite, which replaced the $\left(A_{3}\right)$ alunite and filled open spaces between the branchings; $\left(\mathrm{A}_{5}\right)$ white, rose, or red, fine-grained, strongly orientated alunite, which appears in the central parts of veins and replaced the branching alunite crystals (Fig. 8d).

At depth, fine- to medium-grained alunite is typically associated with silicified hydrothermal breccia matrix and zones of vuggy or massive silica containing disseminated sulfides. Three types of alunite were observed: $\left(B_{1}\right)$ medium- to finegrained, oriented alunite (Fig. 8e) associated with pyrite and woodhouseite-svanbergite (Fig. 9a,b); $\left(\mathrm{B}_{2}\right)$ coarse-grained unoriented alunite with minor pyrite in veins with diffuse contacts; $\left(\mathrm{B}_{3}\right)$ coarsegrained alunite that cuts pervasive pyrite zones (Fig. 8f). All of these alunite types may be crosscut by kaolinite- and pyrophyllite-rich veins, some of which contain andalusite replaced by pyrophyllite or 'sericite', diaspore, and kaolinite. Small enargiteluzonite inclusions in pyrite were identified (Fig. $9 \mathrm{c}, \mathrm{d})$, as well as chalcopyrite, bornite, covellite, and small grains of native copper and silver, galena, and sphalerite. Native gold occurs in the pyrophyllitic matrix and as fine inclusions in covellite. The $\mathrm{Au}$ contents in silica zones are up to $4.5 \mathrm{~g} \mathrm{t}^{-1}$ (ppm). Within small shear zones, foliated alunite that recrystallized around fine-grained pyrite crystals displays local slickenside structures. EDS analyses of woodhouseite-svanbergite (Fig. 9b) show Sr, Ca, $\mathrm{S}$, and $\mathrm{P}$ contents similar to those in the minerals described by Stoffregen and Alpers (1987) in the high-sulfidation epithermal deposit of Summitville (USA) and the Cu-porphyry of La Escondida (Chile).
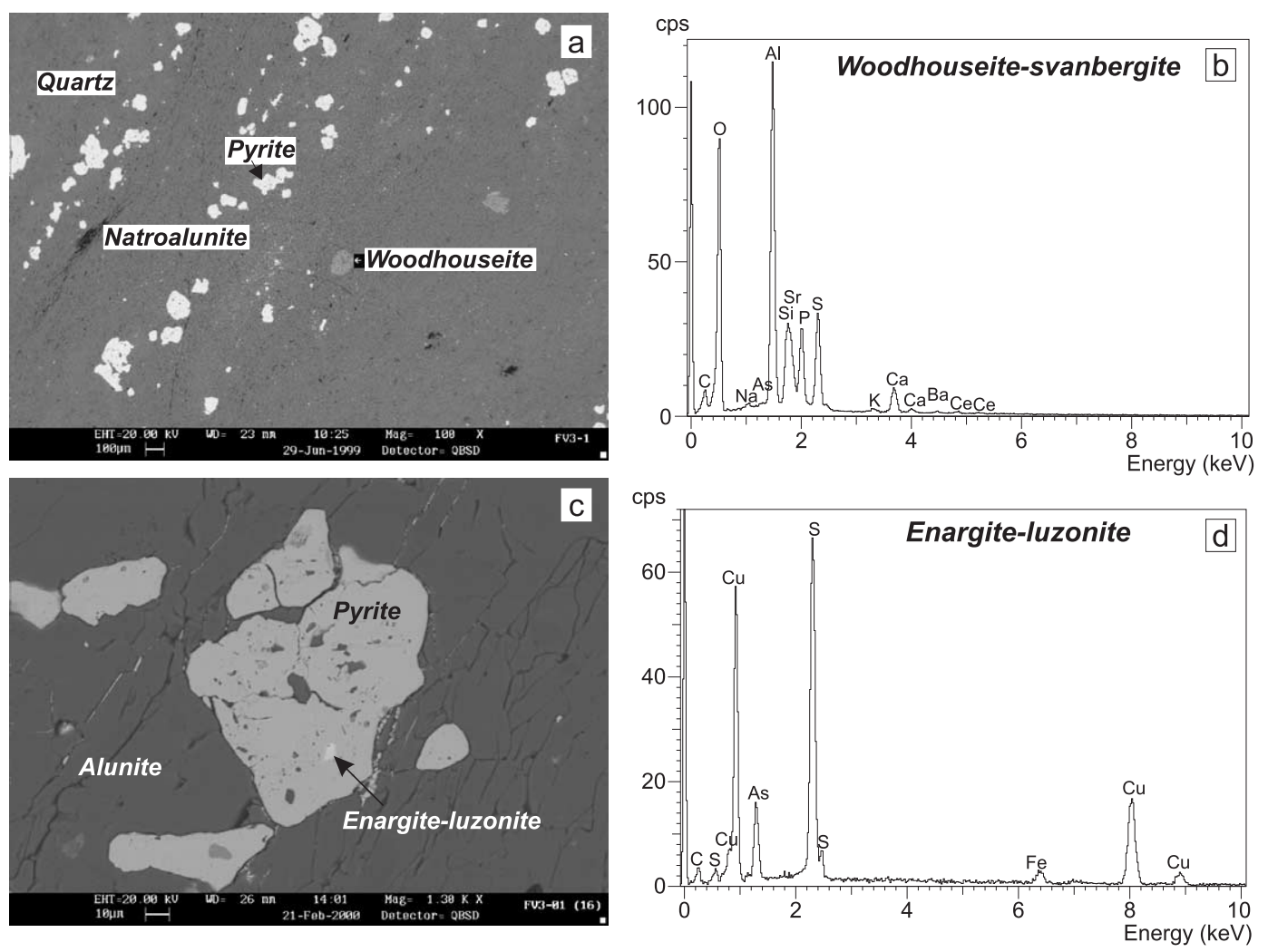

Fig. 9. SEM backscattered-electron images and the corresponding EDS spectra of minor minerals associated with the advanced argillic alteration with alunite. 


\subsubsection{Advanced argillic alteration}

Advanced argillic alteration assemblages are mainly observed in and around the hydrothermal breccia bodies. Within this alteration zone, incipient silicification with associated sulfides was followed by brecciation, pyrophyllitization, and late crystallization of kaolinite-illite and hematite near the surface. The advanced argillic alteration occurs as either a pervasive or fissure-filling assemblage of pyrophyllite+ quartz \pm pyrite \pm andalusite \pm diaspore \pm rutile. Woodhouseite-svanbergite, tourmaline, fluorite, and hematite are also present. The andalusite crystals are euhedral to anhedral, fractured, and partly pyrophyllitized and kaolinitized, with associated diaspore. The pyrophyllite andalusite+quartz assemblage indicates temperatures greater than $330{ }^{\circ} \mathrm{C}$ for the advanced argillic alteration (Hemley et al., 1980). A decreasing temperature of hydrothermal fluids is indicated by the diaspore+pyrophyllite+kaolinite association, which locally replaced andalusite in the advanced argillic alteration. Locally, pyrophyllite is replaced by 'sericite'. In some parts of this alteration zone, early silicification was not observed, and the rock is composed of microcrystalline pyrophyllite with diaspore, rutile, and hematite, locally with andalusite and fine-grained corundum crystals.

\subsubsection{Intermediate argillic alteration}

The intermediate argillic alteration assemblages occur in outcrops close to an eroded body of hydrothermal breccias. In drill cores, the alteration typically forms veins in the pyrophyllitized and alunitized rocks, or forms centimeter-thick zones within the sericitic alteration. The intermediate argillic alteration is characterized by the presence of kaolinite, locally with dickite, 'sericite', chlorite, and feldspar remnants. In addition, this alteration type is observed as thin veins with outer margins of 'sericite' in rocks that underwent propylitic alteration, especially in the deeper levels of the hydrothermal breccias. These veins are more abundant in the deeper sericitic zone, where they increase in volume and acquire a more pervasive style in proximity to the zones of advanced argillic alteration.

\subsubsection{Sericitic alteration}

Weak fissure-controlled sericitic alteration was generally superimposed on the propylitic alteration.
Pervasive sericitization is most conspicuous in the deeper outer alteration halo around the hydrothermal breccias and underlies the advanced argillic zone. Silicification zones are commonly linked to this alteration zone. The rocks most affected are the ash flow tuffs, which show strong replacement by 'sericite', with subordinate clay minerals. Rhyolitic ash flow tuffs at the base of the ring volcanic structure were altered in selective pervasive style, with partial sericitization of the felsic matrix, clasts, and feldspar phenocrysts, with associated finegrained zeolites. Alunite-, pyrophyllite- and pyritebearing zones are present locally, and pyrophyllitic or kaolinite veins are common within sericitic zones.

\subsubsection{Propylitic alteration}

Propylitization occurred in deeper parts of the ring volcano, especially in the dacitic rocks. The intermediate and acid rocks of the Bom Jardim and Salustiano formations are also propylitized in areas farther from the ring volcanic centers, thus indicating that the external alteration halo is predominantly propylitic.

The propylitization style is generally pervasive but is locally of a fissure-filling type, controlled by the igneous or volcaniclastic layering in deeper zones, or by volcanic brecciation. The typical assemblage is chlorite+epidote+carbonate+feldspar+'sericite' \pm quartz \pm pyrite.

The hydrothermal breccias beneath the advanced argillic alteration zones are propylitized, have a pyrite-rich matrix, and commonly show the effects of sericitization or pyrophyllitization in thin fissures. Toward the top of the volcanic vent, the volume and thickness of the micaceous veins increase, as do small discontinuous veins that contain alunite+pyrite rather than the sulfide assemblage.

\subsubsection{Alkali metasomatism}

Alkali metasomatism was recognized in the granites, granophyres, and porphyries of the ringstructure volcanic complexes (Fig. 4). This alteration is pervasive and similar to the one described by Corrêa-Silva et al. (2000) and Juliani et al. (2002) in the Batalha gold-mineralized granite in the Tapajós gold province. The early alteration was 
$\mathrm{Na}$ metasomatism, characterized by irregular and discontinuous albite crystallization on magmatic plagioclase and perthitic K-feldspar rims. As Na metasomatism decreased, $\mathrm{K}$ metasomatism increased; the latter is characterized by microcline, accompanied by green biotite, which replaced magmatic biotite and amphibole. The hydrothermal microcline occupies intercrystal spaces, surrounds the igneous feldspars and quartz, and shows corrosion textures defined by concave inner contacts and irregular shredded rims. Commonly, irregular coalescent veins of microcline, not following the crystallographic orientation of the older feldspars, almost completely replace plagioclase and K-feldspar. The hydrothermal feldspars are cloudy under the microscope and macroscopically are reddish due to the presence of hematite microcrysts. Hydrothermal quartz, tourma- line, and fluorite are ubiquitous as disseminated grains and in veins with carbonates. In the granitic rocks, propylitic and sericitic alteration are younger than the $\mathrm{K}$ metasomatism.

\subsection{Postmineralization metamorphism}

Very little is known about the details of regional and thermal metamorphism in the Tapajós gold province. Postmineralization tectonic events were largely associated with the development of taphrogenic and intracratonic basins after the conclusions of the Parauari magmatic arc evolution (Table 1). A possible reason for the preservation of the Tapajós high-sulfidation mineralization from erosion and weathering could be the generation of shallow pull-apart basins in NW-trending shear zones in a
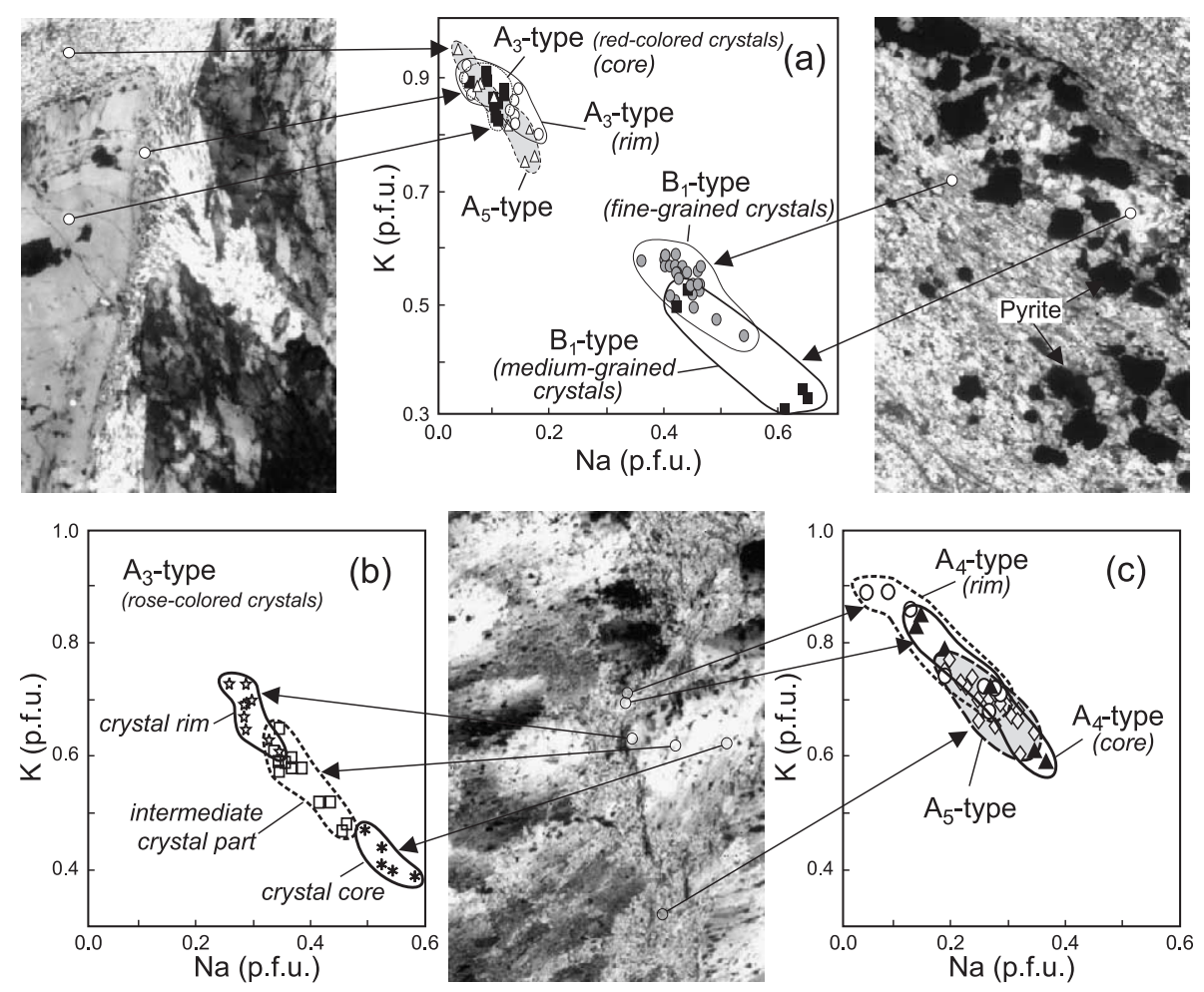

Fig. 10. Plots of electron microprobe data showing the Na and $\mathrm{K}$ contents per formula unit (pfu) in the different types of Tapajós alunite. (a) Coarse-grained alunite crystals $\left(A_{3}\right.$ type) with recrystallized rims partly replaced and enclosed by fine-grained foliated alunite $\left(A_{5}\right.$ type $)$ and $B_{1}-$ type medium- and fine-grained alunite. (b) Coarse-grained $\mathrm{A}_{3}$-type alunite crystals. (c) Fine- to medium-grained alunite crystals ( $\mathrm{A}_{4}$ type) partly replaced by fine-grained alunite $\left(\mathrm{A}_{5}\right.$ type). Photomicrographs are with transmitted light, crossed polars, larger photo side $=3.5 \mathrm{~mm}$. 
retroarc environment related to the Parauari magmatic arc evolution (Juliani et al., 2003). In general, the volcanic and igneous rocks appear remarkably unmetamorphosed. Near the vicinities of the highsulfidation mineralization areas, volcanic and intrusive rocks may be locally deformed along brittle or brittle-ductile shear zones. 'Sericite' appears in acid rocks and chlorite \pm 'sericite' \pm epidote \pm zeolite occur in mafic rocks, but how much of these assemblages are related to regional metamorphism or later hydrothermal alteration is unknown. The general lack of schistosity in the volcanic and igneous host rocks, except along shear zones, and the sporadic occurrence of zeolites suggest that the caldera complex region was probably affected by no more than a very low-grade metamorphism after mineralization. As discussed below, postmineralization metamorphism had little affect on the texture, chemistry, and isotopic composition of alunite in the hydrothermal alteration.

\subsection{Chemical composition of alunite}

Representative microprobe analyses of alunite from deep- $\left(\mathrm{B}_{1}\right.$-type $)$ and shallow-level $\left(\mathrm{A}_{3^{-}}, \mathrm{A}_{4^{-}}\right.$, $\mathrm{A}_{5}$-type) samples of the ring-volcano structure are presented in Table 2. The alunite-group mineral formulae calculated on the basis of $\mathrm{XO}_{4}=2$ (Jambor, 1999) have atomic K ranging from 0.95 to 0.32 , and atomic $\mathrm{Na}$ from 0.66 to 0.04 , and in local occurrences, the mineral contains up to 0.04 atoms $\mathrm{Fe}^{3+}, 0.06$ atoms $\mathrm{P}$, and 0.03 atoms $\mathrm{Sr}$ per formula unit. Thus, the compositional range extends from alunite to natroalunite. The electron microprobe analyses of the alunite indicate an absence of $\mathrm{Pb}$ and, in wt.\%, up to $0.07 \mathrm{As}$, $0.09 \mathrm{Cu}, 0.19 \mathrm{Zn}, 0.04 \mathrm{Cl}$, and 2.02 F. Deep-level, medium-grained $\left(\mathrm{B}_{1}\right.$-type) crystals typically correspond to natroalunite with the highest analyzed $\mathrm{Na}$ content. Fine-grained ( $\mathrm{B}_{1}$-type) crystals, which are strongly oriented along the hydrothermal conduit and partly replace the preexistent crystals, are relatively

Table 3

Summary of ${ }^{40} \mathrm{Ar} /{ }^{39} \mathrm{Ar}$ age spectrum results for alunite

\begin{tabular}{|c|c|c|c|c|c|}
\hline Sample \# & $\begin{array}{l}\text { Alunite } \\
\text { type }\end{array}$ & Event & $\begin{array}{l}\text { Apparent } \\
\text { age (Ma) }\end{array}$ & Type of Age & Comment \\
\hline FV3-1-11 ${ }^{\mathrm{a}}$ & $\mathrm{B}_{1}$ & Mineralization & $1867 \pm 2$ & $\begin{array}{l}\text { Weighted } \\
\text { mean }\end{array}$ & $\begin{array}{l}\text { Near plateau defined by } 83.6 \% \\
\text { of released }{ }^{39} \mathrm{Ar} ; T_{\max }=1871 \mathrm{Ma}\end{array}$ \\
\hline $\mathrm{X} 1-16-18$ & $\mathrm{~A}_{3}$ & Mineralization & $1869 \pm 2$ & Maximum & $\begin{array}{l}\text { Apparent Ar loss with age rising } \\
\text { from } 1750 \text { to } 1869 \mathrm{Ma}\end{array}$ \\
\hline FV3-1-25 & $\mathrm{B}_{3}$ & & $1858 \pm 2$ & Plateau & $\begin{array}{l}\text { Plateau defined by } 62.3 \% \text { of released }{ }^{39} \mathrm{Ar} \text {; } \\
\text { apparent Ar loss, age rises to } 1862 \pm 4 \mathrm{Ma}\end{array}$ \\
\hline FV3-2-7 & $\mathrm{B}_{2}$ & Cooling & $1857 \pm 2$ & Maximum & $\begin{array}{l}\text { Apparent Ar loss with age rising from } \\
1721 \text { to } 1857 \mathrm{Ma}\end{array}$ \\
\hline $\mathrm{X} 1-16-\mathrm{F}^{\mathrm{a}}$ & $\mathrm{A}_{5}$ & and (or) & $1853 \pm 3$ & Plateau & Plateau defined by $85.3 \%$ of released ${ }^{39} \mathrm{Ar}$ \\
\hline X1-16-G & $\mathrm{A}_{3}$ & thermal & $1851 \pm 2$ & $\begin{array}{l}\text { Weighted } \\
\text { mean }\end{array}$ & $\begin{array}{l}\text { Near plateau defined by } 43 \% \text { of } \\
\text { released }{ }^{39} \mathrm{Ar} ; T_{\max }=1854 \mathrm{Ma}\end{array}$ \\
\hline FV3-1-16 (2) & $\mathrm{B}_{1}$ & resetting & $1846 \pm 2$ & Plateau & $\begin{array}{l}\text { Plateau defined by } 62 \% \text { of released }{ }^{39} \mathrm{Ar} \\
\text { apparent Ar loss, age rises to } 1850 \mathrm{Ma}\end{array}$ \\
\hline FV3-1-16 ${ }^{\mathrm{a}}(1)$ & $\mathrm{B}_{1}$ & $\downarrow$ & $1834 \pm 17$ & Plateau & $\begin{array}{l}\text { Plateau defined by } 93.7 \% \text { of released }{ }^{39} \mathrm{Ar} \text {; } \\
\text { large error due to low }{ }^{39} \mathrm{Ar} \text { abundance; } \\
\text { apparent Ar loss, age rises to } 1853 \mathrm{Ma}\end{array}$ \\
\hline FV3-1-12 & & Shearing & $1805 \pm 2$ & Maximum & $\begin{array}{l}\text { Apparent Ar loss with age rising } \\
\text { from } 1184 \text { to } 1805 \mathrm{Ma}\end{array}$ \\
\hline FV3-3-3 & & $\begin{array}{l}\text { Supergene/ } \\
\text { climatic effects }\end{array}$ & $51.3 \pm 0.1$ & $\begin{array}{l}\text { Weighted } \\
\text { mean }\end{array}$ & $\begin{array}{l}\text { Excess Ar; near plateau in saddle defined by } \\
46.3 \% \text { of released }{ }^{39} \mathrm{Ar} \text {; isochron reflects } \\
\text { mixing of three or more Ar reservoirs }\end{array}$ \\
\hline
\end{tabular}

$X$ in sample number refers to surface sample; FV in sample number refers to core sample.

${ }^{\text {a }}$ Breakseal-encapsulated. 
Table 4

Summary of stable-isotope data for alunite and coexisting pyrite and argon age data for alunite

\begin{tabular}{|c|c|c|c|c|c|c|c|c|c|c|c|}
\hline Location & Sample & $\begin{array}{l}\text { Depth } \\
\text { (m) }\end{array}$ & Mineral & $\begin{array}{l}\text { Alunite } \\
\text { type }\end{array}$ & $\begin{array}{l}\delta \mathrm{D} \\
(\% \circ)\end{array}$ & $\begin{array}{l}\delta^{34} \mathrm{~S} \\
(\% 0)\end{array}$ & $\begin{array}{l}\delta^{18} \mathrm{O}_{\mathrm{SO}_{4}} \\
(\% o)\end{array}$ & $\begin{array}{l}\delta^{18} \mathrm{O}_{\mathrm{OH}} \\
(\% \circ)\end{array}$ & $\begin{array}{l}\mathrm{S} \text { isotope } \\
\left(T,{ }^{\circ} \mathrm{C}\right)\end{array}$ & $\begin{array}{l}\mathrm{SO}_{4}-\mathrm{OH} \\
\left(T,{ }^{\circ} \mathrm{C}\right)\end{array}$ & $\begin{array}{l}{ }^{40} \mathrm{Ar} /{ }^{39} \mathrm{Ar} \\
(\text { age }, \mathrm{Ma})^{\mathrm{a}}\end{array}$ \\
\hline Surface & X1-16-9A & Surface & Alunite & $\mathrm{A}_{3}$ & -55 & 36.9 & 16.7 & 11.2 & $140^{\mathrm{b}}$ & 150 & \\
\hline Surface & X1-16-9B & Surface & Alunite & $\mathrm{A}_{5}$ & -52 & 19.6 & 13.9 & 10.2 & $270^{\mathrm{b}}$ & 270 & \\
\hline Surface & $\mathrm{X} 1-16 / \mathrm{G}$ & Surface & Alunite & $\mathrm{A}_{3}$ & & 38.2 & & & $130^{\mathrm{b}}$ & & $1851 \pm 2$ \\
\hline Surface & $\mathrm{X} 1-16 / \mathrm{F}$ & Surface & Alunite & $\mathrm{A}_{5}$ & & 14.3 & & & $420^{\mathrm{b}}$ & & $1853 \pm 3$ \\
\hline Surface & X1-16-18 & Surface & Alunite & $\mathrm{A}_{3}$ & & 26.7 & 13.3 & 7.4 & $250^{\mathrm{b}}$ & 130 & $1869 \pm 2$ \\
\hline Surface & X1-16-19 & Surface & Alunite & $\mathrm{A}_{3}$ & -43 & 25.7 & 11.8 & 6.8 & 210 & 170 & \\
\hline Surface & X1-29-1 & Surface & Pyrite & & & 1.0 & & & & & \\
\hline DDH 1 & FV3-01-16 & 70.9 & Alunite & $\mathrm{B}_{1}$ & & 18.2 & & & & & $1846 \pm 2$ \\
\hline DDH 1 & FV3-01-16 & 70.9 & Pyrite & & & -1.2 & & & 300 & & \\
\hline DDH 1 & FV3-1-11 & 55.1 & Alunite & $\mathrm{B}_{1}$ & & 15.8 & & & & & $1867 \pm 2$ \\
\hline DDH 1 & FV3-1-11 & 55.1 & Pyrite & & & -6.3 & & & 260 & & \\
\hline DDH 1 & FV3-1-12 & 58.2 & Alunite & Recryst & & 12.4 & & & & & $1805 \pm 2$ \\
\hline DDH 1 & FV3-1-17 & 71.8 & Alunite & $\mathrm{B}_{1}$ & & 17.4 & & & & & \\
\hline DDH 1 & FV3-1-17 & 71.8 & Pyrite & & & 0.1 & & & 330 & & \\
\hline DDH 1 & FV3-1-17 & 71.8 & Alunite & $\mathrm{B}_{2}$ & & 16.0 & & & & & \\
\hline DDH 1 & FV3-1-17 & 71.8 & Pyrite & & & -1.5 & & & 320 & & \\
\hline DDH 1 & FV3-1-25 & 129.8 & Alunite & $\mathrm{B}_{3}$ & & 14.0 & & & $420^{\mathrm{b}}$ & & $1858 \pm 2$ \\
\hline DDH 1 & FV3-1-34 & 184.2 & Alunite & $\mathrm{B}_{1}$ & & 16.4 & & & & & \\
\hline DDH 1 & FV3-1-34 & 184.2 & Pyrite & & & -3.2 & & & 290 & & \\
\hline DDH 2 & FV3-2-9 & 145.5 & Alunite & $\mathrm{B}_{2}$ & & 21.6 & & & & & \\
\hline DDH 2 & FV3-2-9 & 145.5 & Pyrite & & & -1.2 & & & 250 & & \\
\hline DDH 2 & FV3-2-7 & 127.8 & Alunite & $\mathrm{B}_{2}$ & & 21.4 & & & $280^{\mathrm{b}}$ & & $1857 \pm 2$ \\
\hline DDH 3 & FV3-3-3 & 66.7 & Alunite & Super & & 4.1 & & & & & $51.3 \pm 0.1$ \\
\hline DDH 3 & FV3-3-3 & 66.7 & Pyrite & & & -1.3 & & & & & \\
\hline DDH 3 & FV3-3-18 & 171.1 & Alunite & $\mathrm{B}_{1}$ & & 19.4 & & & & & \\
\hline DDH 3 & FV3-3-18 & 171.1 & Pyrite & & & 1.7 & & & 320 & & \\
\hline DDH 3 & FV3-3-19 & 184.5 & Alunite & $\mathrm{B}_{1}$ & & 19.6 & & & & & \\
\hline DDH 3 & FV3-3-19 & 184.5 & Pyrite & & & 1.0 & & & 310 & & \\
\hline
\end{tabular}

Abbreviations: DDH—drillhole; recryst—recrystallized; super-supergene.

${ }^{a}$ Appendix A.

b Assumed $\delta^{34} \mathrm{~S}_{\mathrm{py}}=1.0$.

enriched in $\mathrm{K}$ (Fig. 9a). The composition of red, coarse-grained branching crystals $\left(\mathrm{A}_{3}\right.$-type) from veins in alunitized rocks below and around the silica cap is that of alunite, with rim crystals slightly more sodic (Fig. 10a). This coarse-grained alunite type is replaced by oriented fine-grained alunite $\left(\mathrm{A}_{5}\right.$-type) (Fig. 10a). Rose-colored branching crystals of $A_{3}$-type alunite in the same hydrothermal alteration zone show decreases in their $\mathrm{Na}$ and $\mathrm{K}$ contents from the cores toward the rims (Fig. 10b). This $\mathrm{A}_{3}$-type natroalunite is replaced by medium- to fine-grained alunite $\left(\mathrm{A}_{4}{ }^{-}\right.$ type), which is slightly more K-rich (Fig. 10c). These $\mathrm{A}_{4}$-type crystals are cut and replaced by veins composed of relatively more sodic fine-grained crystals $\left(\mathrm{A}_{5}\right.$; Fig. 10c), which are strongly oriented along the vein. However, the $\mathrm{A}_{5}$-type alunite may also have $\mathrm{K}$ enrichment towards the rims in red-colored alunite samples (Fig. 10a).

The relationships among alunite composition, hydrothermal fluid evolution, and deformational events are not understood well, but the data indicate a systematic decrease of $\mathrm{Na}$ and increase of $\mathrm{K}$ contents in the later crystallization stages and in the later fine-grained alunite generations that replaced the coarse-grained alunite. This $\mathrm{Na}-\mathrm{K}$ zonation could be an indication of decreasing temperature of the hydrothermal system (Stoffregen and Cygan, 1990; Stoffregen et al., 2000). The branching alunite in veins ( $\mathrm{A}_{3}$-type) occurs only at shallow levels, whereas finegrained natroalunite $\left(\mathrm{B}_{1}\right.$-type $)$ occurs in deeper zones, 
suggesting decreasing temperature from the bottom to the top. However, as discussed in Section 4.7 on stable isotopes, localized pulses of relatively hotter hydrothermal fluids might be indicated by crystallization of branching natroalunite $\left(\mathrm{A}_{3}\right.$-type $)$ in veins under the silica cap, and by the later fine-grained alunite of the $\mathrm{A}_{5}$-type.

\subsection{Ar-Ar dating of alunite}

A summary of ${ }^{40} \mathrm{Ar} /{ }^{39} \mathrm{Ar}$ age spectra for alunite samples is given in Appendix A, and the interpretation in terms of geological processes is presented in Table 3. These ages are also shown with stableisotope data in Table 4. Fig. 11 includes results for eight of the nine alunite spectra analyzed from the Tapajós gold prospect. Seven of these spectra yield plateaus or high-temperature maximum ages that fall between $1869 \pm 2$ Ma (high-temperature age for sample X1-16-18) and 1846 \pm 2 Ma (plateau age for sample FV3-1-16), and show variable amounts of apparent ${ }^{40} \mathrm{Ar}$ loss in the lower temperature steps. Detailed discussion of Ar retention for these samples is given in a companion paper (Landis et al., this volume). As discussed in that paper, the cluster of ages is interpreted to represent formation of the magmatic-hydrothermal alunite in the high-sulfidation deposit at $\sim 1869$ Ma. The younger apparent ages, ranging down to $1846 \mathrm{Ma}$, are interpreted to reflect various degrees of postcrystallization resetting, which resulted from prolonged thermal activity in the region after $1869 \mathrm{Ma}$. The possibility that multiple periods of alunite formation may have occurred is not excluded, but it is unlikely that a high-sulfidation mineralization event existed for the entire 20 my period.

Also shown in Fig. 11 is the age spectrum for alunite sample FV3-1-12, which occurs within small shear zones and displays slickenside structures that indicate clearly its deformation and recrystallization by younger tectonic activity. The age spectrum exhibits an increase in apparent ages with increasing release temperature, a pattern characteristic of apparent ${ }^{40} \mathrm{Ar}$ loss. This mixing of younger $\mathrm{Ar}$ in the lower temperature steps with older $\mathrm{Ar}$ in higher temperature steps is interpreted to be a result of later tectonic and thermal activity of unknown age.

Figs. 12 and 13 are the age spectrum and isochron diagrams, respectively, for FV3-3-3 alunite. The age spectrum has the classic U-shaped character attribut-

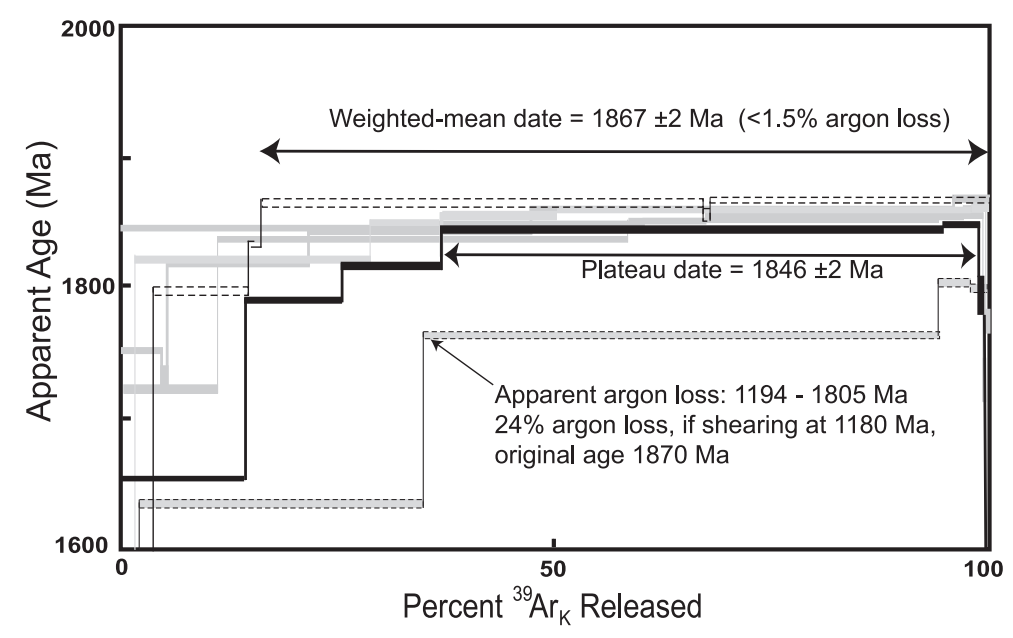

Fig. 11. Composite ${ }^{40} \mathrm{Ar} /{ }^{39} \mathrm{Ar}$ age spectrum diagram showing age spectra of eight magmatic-hydrothermal alunite samples from the Tapajos gold province. Plateaus or high-temperature release ages for seven of these spectra lie between $1869 \pm 2$ and $1846 \pm 2$ Ma. Interpreted age of highsulfidation system is $1869 \mathrm{Ma}$; younger ages reflect extended cooling or partial resetting of the Ar systematics between 1869 and 1846 Ma. Apparent Ar loss in lower temperature release steps may be due to younger structural or thermal activity. Age spectrum showing apparent Ar loss from 1194 to $1805 \mathrm{Ma}$ is for a deformed alunite and reflects younger structural and thermal activity that locally affected the deposit. Details of interpretation are discussed in Landis et al. (this volume). 


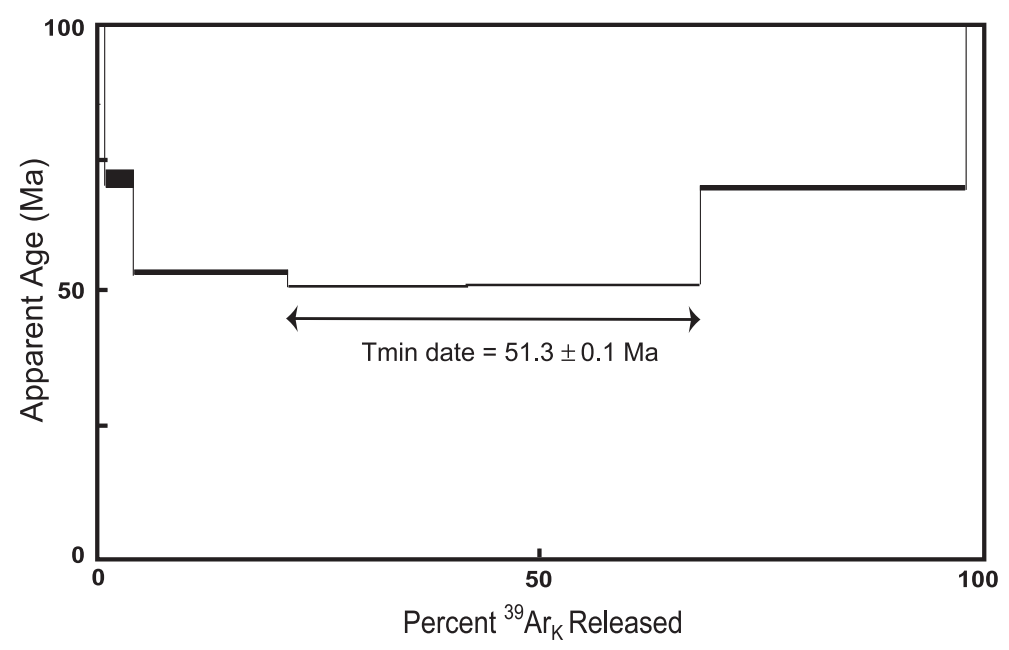

Fig. 12. The ${ }^{40} \mathrm{Ar}{ }^{39} \mathrm{Ar}$ age-spectrum diagram for supergene alunite sample FV3-3-3. The U-shaped spectrum is typical for a sample containing excess ${ }^{40} \mathrm{Ar}$. Despite the presence of excess Ar, the apparent age of two temperature steps comprising $46.3 \%$ of the total released ${ }^{39} \mathrm{Ar}$ is $51.3 \pm 0.1 \mathrm{Ma}$ and is interpreted to be the maximum age for the formation of the supergene alunite.

able to incorporation of excess ${ }^{40} \mathrm{Ar}$. Despite the presence of this excess Ar, more than $46 \%$ of the ${ }^{39} \mathrm{Ar}$ released in two temperature steps defines an apparent age of $51.3 \pm 0.1 \mathrm{Ma}$, interpreted to represent the maximum estimate for the age of formation through supergene processes. The isochron diagram confirms this apparent age and shows that a second component of radiogenic $\mathrm{Ar}$ with a Proterozoic signature is present in the sample. We interpret this older $\mathrm{Ar}$ reservoir to be incorporated from Ar released from older country rocks during the processes that formed this supergene alunite.

\subsection{Stable isotopic data}

The stable-isotope studies reported here are preliminary and are limited in scope. They are designed to determine the kinds of alunite present at

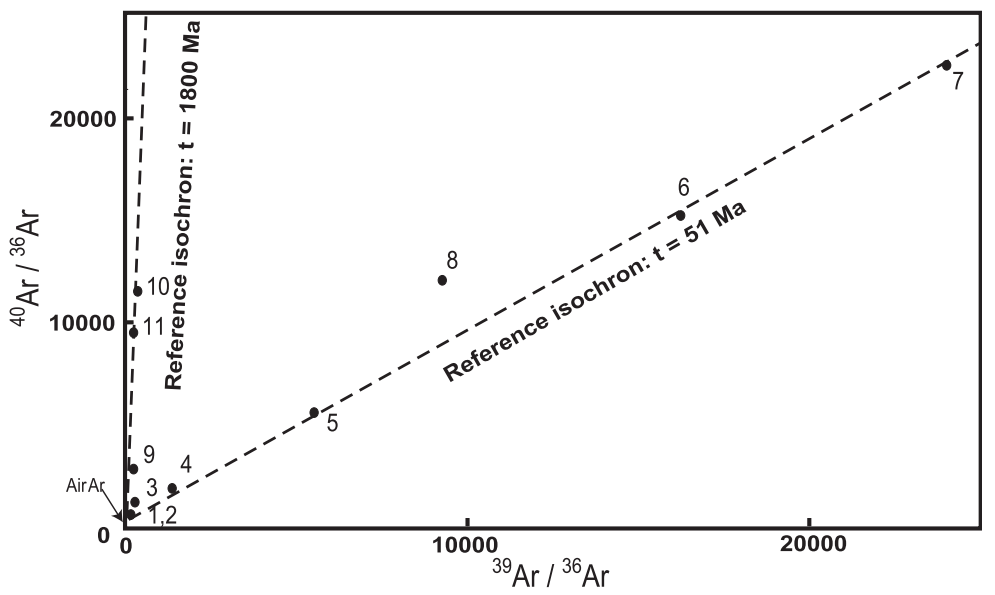

Fig. 13. ${ }^{40} \mathrm{Ar} /{ }^{36} \mathrm{Ar}$ vs. ${ }^{39} \mathrm{Ar} /{ }^{36} \mathrm{Ar}$ isochron diagram for supergene alunite samples. Data for 11 temperature steps are bracketed by two reference isochrons with ages of 51 and $1800 \mathrm{Ma}$. The distribution of data indicates two reservoirs of radiogenic Ar with apparent ages of approximately $51 \mathrm{Ma}$ and Proterozoic ages. Isochron analysis supports the interpretation that the formation age of supergene alunite is $\leq 51 \mathrm{Ma}$, and that minor excess Ar released from host rocks during their weathering was incorporated. 
Tapajós and to verify the presence of magmatichydrothermal alunite in the hydrothermal alteration associated with high-sulfidation mineralization. In Table 4 , the $\delta^{34} \mathrm{~S}$ values of alunite range from $4.1 \%$ to $38.2 \%$, and values for coexisting pyrite range from $-6.3 \%$ to $1.7 \%$. All except two $\delta^{34} \mathrm{~S}$ alunite values are greater than $14.3 \%$. The exceptions are (1) a sample from shallow depth (FV3-3-3; Table 4), which has a $\delta^{34} \mathrm{~S}$ value of $4.1 \%$ and an Ar age of $51 \mathrm{Ma}$, and which is obviously supergene; (2) a recrystallized sample with a value of $12.4 \%$, also from a shallow depth in a drillhole (FV3-1-12; Table 4). This sample has lost Ar and has an age of 1805 Ma. Sulfur-isotope exchange may occur in sulfate minerals during recrystallization in the presence of sulfur-bearing fluids, and the $\delta^{34} \mathrm{~S}$ value of this sample may not be primary.
All aspects of the stable-isotope data are typical of classical magmatic-hydrothermal alunite observed in studies of many high-sulfidation-type ore deposits, including Summitville, Colorado (Bethke et al., this volume); Julcani, Peru (Deen, 1990); Rodalquilar, Spain (Arribas et al., 1995); Lepanto, Phillipines (Hedenquist et al., 1998); Pierina, Peru (Fifarek and Rye, this volume); and Tambo, Chile (Deyell et al., this volume). The large $\delta^{34} \mathrm{~S}$ values of all primary hydrothermal alunite require a magmatic-hydrothermal origin (Rye et al., 1992; Arribas, 1995). This type of alunite forms from sulfuric acid created during the disproportionation of $\mathrm{SO}_{2}$ during the condensation of a cooling magmatic vapor plume that arises from the brittle-ductile transition beginning at about $400{ }^{\circ} \mathrm{C}$ (Rye, 1993; Fournier, 1999). The large $\delta^{34} \mathrm{~S}$ values result from equilibration of aqueous sulfate with $\mathrm{H}_{2} \mathrm{~S}$

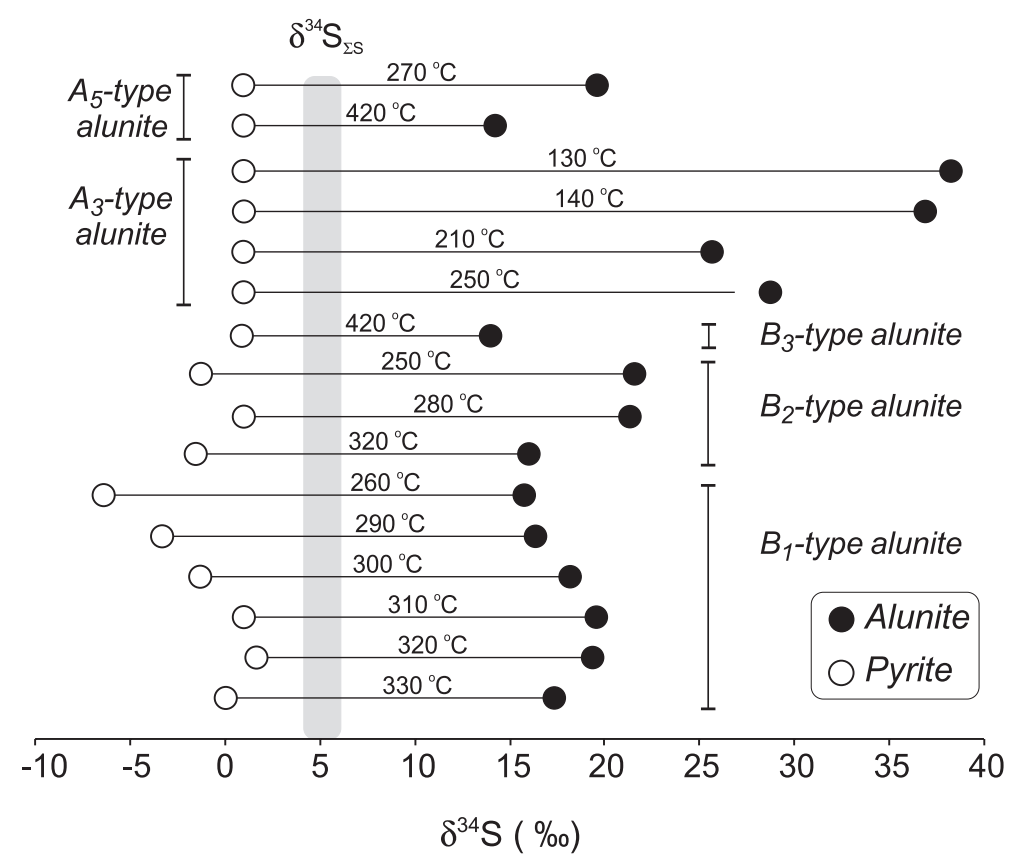

Fig. 14. The $\delta^{34} \mathrm{~S}$ values of alunite and coexisting pyrite in surface and drillhole samples of alunite from the silica cap, with an assumed $\delta^{34} \mathrm{~S}$ value of $1.0 \%$ for pyrite that has been removed by oxidation. Temperatures are based on calculations using the empirical equations of Ohmoto and Rye (1979) and Ohmoto and Lasaga (1982). The shaded rectangle represents a reasonable value, based on the lever rule, for the $\delta^{34} \mathrm{~S}$ of the bulk sulfur in the hydrothermal fluids prior to their ascent from the brittle-ductile transition. The implied reduced $\left(\mathrm{H}_{2} \mathrm{~S} / \mathrm{SO}_{4}^{2-} \geq 1\right)$ nature of the starting fluids, as shown by the position of the shaded rectangle, is reflected by the fact that, for the dataset as a whole, most of the change in $\delta^{34} \mathrm{~S}$ is in the alunite. Locally, however, as indicated by the $\mathrm{B}_{1}$ samples, the change in $\delta^{34} \mathrm{~S}$ is greater in pyrite, thus indicating a shift to fluids with $\mathrm{H}_{2} \mathrm{~S}_{2} \mathrm{SO}_{4}^{2-}$ of $<1$ as $\mathrm{H}_{2} \mathrm{SO}_{4}$ was formed from the disproportionation of $\mathrm{SO}_{2}$ at the site of alunite crystallization. Samples are arranged by type and calculated temperature. 
in the parent fluids whose $\mathrm{H}_{2} \mathrm{~S}_{/} \mathrm{SO}_{4}^{2-}$ was initially $>1$ (Rye, 1993).

Another characteristic of magmatic-hydrothermal alunite is that the sulfur-isotope fractionations between alunite and pyrite give reasonable depositional temperatures, reflecting isotopic equilibrium between parental aqueous sulfur species (Rye et al., 1992; Rye, this volume). Fig. 14 summarizes thermometry data (Table 4) based on sulfur isotopic fractionations in coexisting alunite and pyrite from the surface and drillholes, using the experimental data of Ohmoto and Lasaga (1982), and in samples in which pyrite is oxidized, an assumed value of $1.0 \%$ o for coexisting pyrite. The surface samples are from the silica cap, whose pyrite generally has been oxidized, but one pyrite sample (X1-29-1) from the cap has a $\delta^{34} \mathrm{~S}$ value of $1 \%$. The $\delta^{34} \mathrm{~S}$ values of most pyrite at Tapajós range from $1.7 \%$ to $-1.3 \%$. Thus, for pyrite removed by oxidation, a $\delta^{34} \mathrm{~S}$ value of $1 \%$ can reasonably be assumed to be typical of the average value in the calculation of alunite-pyrite sulfurisotope temperatures in Table 4. As an example of the uncertainty in calculated temperatures using this assumption, a $\pm 2 \%$ o change in the $\delta^{34} \mathrm{~S}$ value for pyrite would result in temperatures of 130 to $180{ }^{\circ} \mathrm{C}$ instead of the $140{ }^{\circ} \mathrm{C}$ shown in Table 4 for sample X116-9A. Furthermore, use of an assumed value of $1 \%$ o for pyrite gives alunite-pyrite temperatures that are in excellent agreement with temperatures determined from the $\mathrm{SO}_{4}-\mathrm{OH}$ oxygen-isotope fractionations in alunite (Table 4). The calculated sulfur isotopic temperatures range from 420 to $130{ }^{\circ} \mathrm{C}$, with the lowest temperature from the surface in the silica cap. The sulfur isotopic temperatures (Table 4; Fig. 14) are consistent with magmatic-hydrothermal alteration in other high-sulfidation systems. The high temperatures for some of the samples are also consistent with the occurrence of andalusite in the alteration assemblages (Hemley et al., 1980).

The sulfur and oxygen isotopic temperatures are consistent with primary hydrothermal alteration temperatures that have not been affected by post-ore metamorphism. The lack of post-ore metamorphic effects on the sulfur-isotope data of pyrite and alunite is consistent with the lack of recrystallization in most samples. It has long been known that stable-isotope exchange in minerals by diffusion is slow, and that sulfur-isotope exchange in ore minerals requires that they be recrystallized in the presence of a sulfurbearing fluid (cf., Ohmoto and Rye, 1979; Casadevall and Rye, 1980; Whelan et al., 1984; Seal et al., 2001). Resetting of sulfur-isotope compositions of hydrothermal sulfates during regional metamorphism is probably rare below greenschist grade. In some instances at Tapajós, the finer-grained (and later) alunite records higher isotope temperatures than those of the coarse alunite it crosscuts. As discussed below, this feature is likely related to temperature fluctuations of the fluids in a dynamic hydrothermal system rather than to the effects of isotopic exchange during metamorphism.

The $\delta^{34} \mathrm{~S}$ values of primary alunite range from $15.8 \%$ to $38.2 \%$, and values for coexisting pyrite range from $-6.3 \%$ o to $1.7 \%$ (Table 4 ). Thus, the range of $\delta^{34} \mathrm{~S}$ values for primary magmatic-hydrothermal alunite is larger than the range for pyrite. Such sulfurisotope systematics are a characteristic of this type of alunite and reflect the initial reduced $\left(\mathrm{H}_{2} \mathrm{~S}_{\mathrm{SO}} \mathrm{SO}_{4}^{2-} \geq 1\right)$ nature of the fluids as a result of their equilibration with crystalline rocks below the brittle-ductile transition in crustal level (Rye, 1993, this volume). Application of the lever rule to the data in Fig. 14 suggests that the $\delta^{34} \mathrm{~S}_{\Sigma \mathrm{S}}$ of the fluids prior to the start of alteration may have been about $5 \%$.

The surface $\mathrm{A}_{3}$-type, coarse-grained alunite is isotopically heavy and gives sulfur isotopic temperatures of about $130-250{ }^{\circ} \mathrm{C}$. This alunite is cut by $\mathrm{A}_{5}-$ type fine-grained isotopically light alunite that yields a temperature of $270-420{ }^{\circ} \mathrm{C}$ (Fig. 14), thus suggesting the occurrence of major fluctuations at shallow levels in the temperature of the magmatic vapor plume that gave rise to the alteration.

The drillhole samples correspond to $B_{1}$-type medium- to fine-grained isotopically light alunite whose sulfur isotopic temperatures are about 260$330{ }^{\circ} \mathrm{C}$, to $\mathrm{B}_{2}$-type coarse-grained, isotopically heavier alunite whose derived temperatures are 250 $320{ }^{\circ} \mathrm{C}$, and to $\mathrm{B}_{3}$-type coarse-grained isotopically light alunite with a temperature of $420{ }^{\circ} \mathrm{C}$ (Fig. 14). Thus, fluctuations of the temperature of the vapor plume in deeper levels of the system are also suggested. This fluctuation in the temperature of the fluids during magmatic-hydrothermal alteration is consistent with the occurrences of hydrothermal breccias at Tapajós and reflects the dynamic nature of the hydrothermal system. The recognition of these 

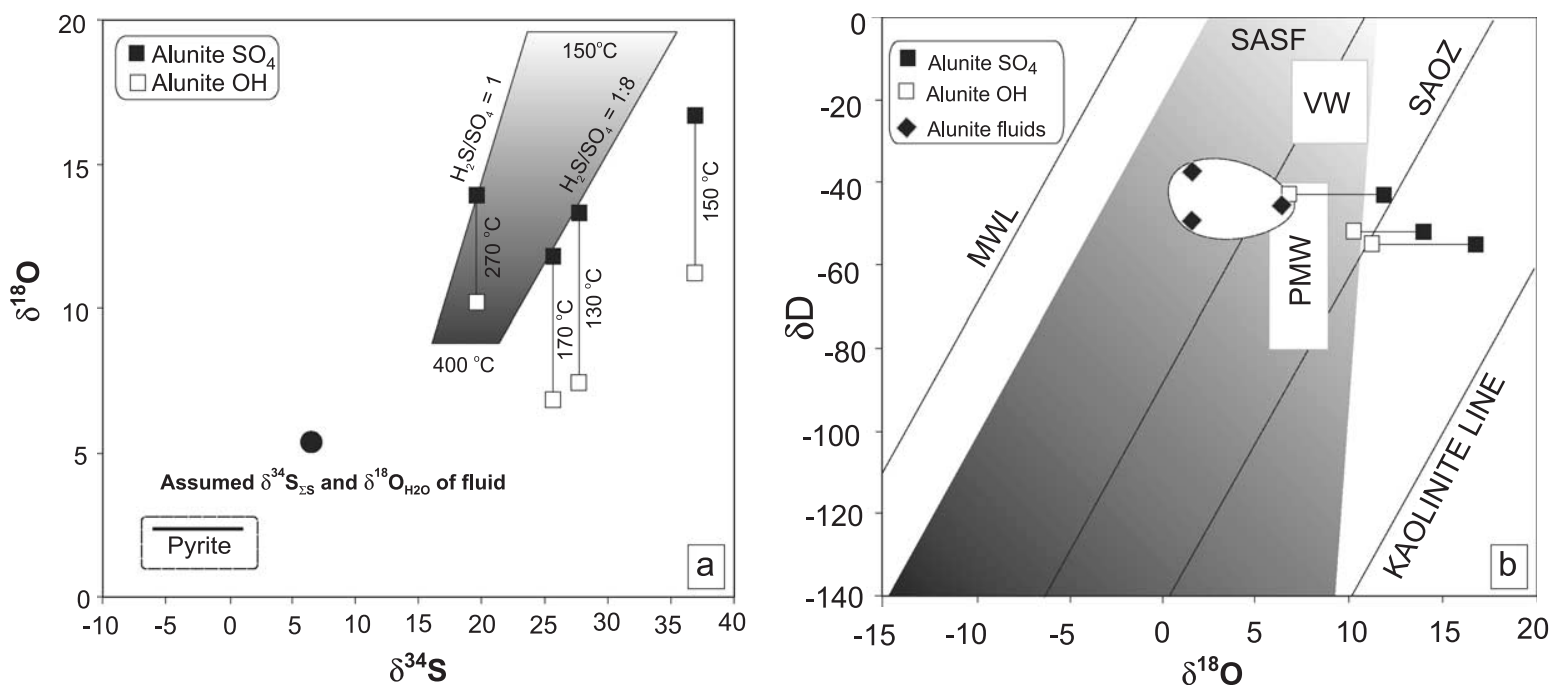

Fig. 15. Plots of the $\delta^{34} \mathrm{~S}, \delta^{18} \mathrm{O}_{\mathrm{OH}}$, and $\delta^{18} \mathrm{O}_{\mathrm{SO}_{4}}$ values (a), and the $\delta \mathrm{D}, \delta^{18} \mathrm{O}_{\mathrm{OH}}$, and $\delta^{18} \mathrm{O}_{\mathrm{SO}_{4}}$ values (b) of alunite. In (a), the tie lines between solid and open symbols represent $\delta^{18} \mathrm{O}_{\mathrm{SO}_{4}-\mathrm{OH}}$ values with temperatures calculated from the experimental curve of Stoffregen et al. (1994). The shaded polygon is the field predicted for $\delta^{34} \mathrm{~S}, \delta^{18} \mathrm{O}_{\mathrm{OH}}$, and $\delta^{18} \mathrm{O}_{\mathrm{SO}_{4}}$ values of magmatic-hydrothermal alunite in isotopic equilibrium with a fluid (solid circle) of $\delta^{18} \mathrm{O}_{\mathrm{H}_{2} \mathrm{O}}=6$ and $\delta^{34} \mathrm{~S}_{\Sigma \mathrm{S}}=5$ at temperatures of 400 to $150{ }^{\circ} \mathrm{C}$ and $\mathrm{H}_{2} \mathrm{~S}_{/} \mathrm{SO}_{4}=1$ to 8 (Rye et al., 1992). The range of $\delta^{34} \mathrm{~S}$ values for pyrite is shown in dashed rectangle. In (b), the compositions of the parental alunite fluids are calculated using the temperatures in (a) based on the empirical fractionations of Stoffregen et al. (1994) and the sulfur-isotope temperatures, which are similar to the $\Delta^{18} \mathrm{O}_{\mathrm{SO}_{4}-\mathrm{OH}}$ temperatures for the same samples shown in (a). Values and equation of the shaded polygon, SASF, are the supergene alunite $\mathrm{SO}_{4}$ reference field of Rye et al. (1992). Other references are primary magmatic water, PMW (Taylor, 1968); volcanic water, VW (Giggenbach, 1997); meteoric water line, MWL (Craig, 1961); and Kaolinite Line (Savin and Epstein, 1970).

temperature variations also argues strongly against a significant postmineralization metamorphic effect in the deposit.

The pyrite associated with the $\mathrm{B}_{1}$-type alunite shows the lowest $\delta^{34} \mathrm{~S}$ values, as well as a greater range of values $(1.7 \%$ o to $-6.3 \%$ ) than does alunite $(15.8 \%$ o to $21.6 \%$ ). These systematics indicate that locally $\mathrm{H}_{2} \mathrm{~S}_{/} \mathrm{SO}_{4}^{2-}$ was $<1$. This change in the oxidation state of the fluids is also typical of magmatic-hydrothermal alunite and is due to the formation of copious amounts of $\mathrm{H}_{2} \mathrm{SO}_{4}$ during disproportionation of $\mathrm{SO}_{2}$ (Rye, this volume; Bethke et al., this volume).

The $\delta \mathrm{D}, \delta^{34} \mathrm{~S}$, and $\delta^{18} \mathrm{O}_{\mathrm{SO}_{4}}$ and $\delta^{18} \mathrm{O}_{\mathrm{OH}}$ values of alunite are summarized in Fig. 15. In Fig. $15 \mathrm{a}$, the $\delta^{34} \mathrm{~S}$ versus $\delta^{18} \mathrm{O}_{\mathrm{SO}_{4}}$ values fall in or near the reference for magmatic-hydrothermal alunite assuming a $\delta^{34} \mathrm{~S}_{\Sigma \mathrm{S}}$ of 5 and $\mathrm{H}_{2} \mathrm{~S} / \mathrm{SO}_{4}$ between 1 and 8 . Values that fall below the reference indicate minor mixing of magmatic fluids with meteoric water, such as observed at Summitville (Bethke et al., this volume).
All of the $\Delta^{18} \mathrm{O}_{\mathrm{SO}_{4}-\mathrm{OH}}$ fractionations (Fig. 15a) give geologically reasonable temperatures. These fractionations commonly give disequilibrium values because of retrograde exchange on the $\mathrm{OH}$ site (Rye et al., 1990; Rye, this volume; Bethke et al., this volume). The fact that these fractionations give such reasonable temperatures probably reflects the low temperature of deposition of the shallow samples. Although minor Ar loss occurred in some alunite samples during regional metamorphism, later resetting of $\Delta^{18} \mathrm{O}_{\mathrm{SO}_{4}-\mathrm{OH}}$ fractionations is not considered very likely.

The $\delta \mathrm{D}$ values (Fig. 15b) are near those of the primary magmatic water (PMW) reference of Taylor (1968) and the volcanic water (VW) reference of Giggenbach (1997), and are typical of magmatic fluids in high-sulfidation systems (Rye et al., 1992; Arribas, 1995; Hedenquist et al., 1998). The $\delta^{18} \mathrm{O}_{\mathrm{H}_{2}} \mathrm{O}$ values are lower than those of typical magmatic water regardless of $\delta \mathrm{D}$ value. This difference is also typical of fluids for magmatic-hydrothermal alunite and likely reflects mixing of magmatic fluids with meteoric 
water (Rye et al., 1992; Rye, 1993; Bethke et al., this volume).

\section{Discussion}

The general geological, mineralogical, and stable isotopic characteristics of the sulfur-bearing minerals described here for the Tapajós gold province are similar to those observed in many younger high-sulfidation ore deposits, such as the Tertiary Yanacocha gold district in Peru (Harvey et al., 1999), the Miocene Summitville deposit in Colorado, USA (Stoffregen, 1987; Rye, 1993; Bethke et al., this volume), the Miocene Lepanto deposit, Philippines (Hedenquist et al., 1998), the Miocene Rodalquilar deposit, Spain (Arribas et al., 1995), as well as the Late Proterozoic Hope Brook mine in Canada (Dubé et al., 1998). The 1.869 \pm 0.002 $\mathrm{Ga}$ age of the magmatic-hydrothermal alunite associated with the Tapajós high-sulfidation mineralization is consistent with a cogenetic origin with the host volcanic and igneous rocks.

There is little evidence of postmineralization regional metamorphism of the host rock Iriri group in the Tapajós gold province. Mineralization occurred at the end of the Parauari orogeny, and the major structural events that followed were likely largely related to the development of taphrogenic and intracratonic basins. The depth of burial of the Tapajós mineral occurrences in these basins is not known. Observations on the country rocks of the highsulfidation mineralization indicate no more than zeolite-facies to low greenschist-facies regional metamorphism. The postmineralization regional deformation seems to have been responsible only for weak local foliation in epiclastic volcanic rocks. The effect of possible regional metamorphism is not observed in the hydrothermal mineral paragenesis. The foliation of alunite is restricted locally to N-S and NW-SE faults, where alunite also displays slickenside structures and is recrystallized.

This shearing reflects a postmineralization tectonic activity, as is indicated by the disturbed Ar and the sulfur isotopic systematics in a single sample (FV3-1$12)$ at Tapajós. This younger tectonic activity could be related to the $1.86-1.52$ Ga Rio Negro or 1.76-1.47 Ga Rondônia-Juruena orogenesis (Fig. 1). Despite possible diverse postmineralization orogenetic events described in the southwestern part of the Tapajós gold province and the Amazonian Craton (Tassinari and Macambira, 1999; Santos et al., 2000), there is no evidence that regional metamorphism affected the texture, primary chemical and isotopic compositions, or Ar age of most of the alunite.

A possible reason for the preservation of the Tapajós high-sulfidation mineralization from erosion and weathering could be the generation of shallow pullapart basins in NW-trending shear zones in a retroarc environment related to the Parauari magmatic arc evolution (Juliani et al., 2003). Rapid burial by fluvial and shallow marine sediments favored preservation from the early weathering and erosion, and preservation was also favored by the tectonic stability of the Tapajós gold province after the Parauari event. Later events had little effect on Ar retention in alunite.

To our knowledge, andalusite has not been described in unmetamorphosed Tertiary high-sulfidation deposits. Advanced argillic alteration with andalusite has been reported at the Upper Cretaceous Chelopech gold deposit, Bulgaria (Andrew, 2002), at the latest Triassic to Middle Jurassic Limonite Creek area, British Columbia (Deyell et al., 2000), at the Paleozoic Brewer mine (Lu et al., 1992), at the Precambrian or lower Paleozoic Mi Vida porphyry $\mathrm{Cu}$ deposit in Argentina (Koukharsky and Mirre, 1976), and at the Late Proterozoic Hope Brook mine in Canada (Dubé et al., 1998). Andalusite in some of these deposits occurs at depths below those of a typical epithermal environment (Dubé et al., 1998; Deyell et al., 2000; Andrew, 2002). However, in the Tapajós high-sulfidation deposit, the occurrence of andalusite close to the silica cap suggests that the mineral formed instead of kaolinite because of the excess silica and relatively high temperatures (about $350-400{ }^{\circ} \mathrm{C}$ ), as predicted by Hemley et al. (1980). These conditions are consistent with the high sulfur-isotope temperatures for some samples of alunite (Fig. 14).

The high-sulfidation mineralization is closely related to calc-alkaline granite, granophyre, and porphyry intrusions, which show high-temperature alkali metasomatism overprinted by propylitic and sericitic alteration similar to those described in the Batalha granite in the Tapajós gold province (Juliani et al., 2002). The Batalha granite is gold-mineralized, and among the characteristics that its hydrothermal system shares with porphyry $\mathrm{Cu}-\mathrm{Au}$ deposits are extensive 
potassic alteration, a high halogen content in biotite, and a base-metal-gold association (Juliani et al., 2002). These characteristics suggest that the Tapajós highsulfidation $\mathrm{Au}$ mineralization might be genetically linked to $\mathrm{Cu}-\mathrm{Au}$ porphyry mineralization as proposed by Sillitoe (1973, 1991), Davidson and Mpodozis (1991), Hedenquist and Lowenstern (1994), and Hedenquist et al. (1998) in studies of more recent but similar tectonic settings. In this context, colluvial and alluvial gold deposits associated with quartz veins hosted by hydrothermalized porphyry and granophyric intrusions, which occur in the high-sulfidation mineralization region (Fig. 5), could be associated with $\mathrm{Cu}-$ Au porphyry and low-sulfidation mineralization styles.

There seems to have been remarkably little supergene alteration of the Tapajós occurrences. Only one sample of supergene alunite (Table 3) has been discovered, and it formed at $51.3 \pm 0.1 \mathrm{Ma}$, probably by unroofing of the deposit during the early Tertiary period of widespread laterization in the southern Amazonian Craton (Faraco et al., 1997; Motta et al., 2000). The erosion of the large areas of the volcanic sequence, which potentially contained epithermal $\mathrm{Au}$ deposits similar to that described in this paper, could have been responsible for concentration of gold in alluvial and colluvial deposits, which have been mined extensively in the Tapajós gold province.

\section{Conclusions}

The high-sulfidation deposit in the Tapajós gold province is the first Paleoproterozoic occurrence discovered in the Amazonian Craton. The geological setting, the nature of the host rocks, the alteration mineralogy, the spatial relationship of the hydrothermal zones, the age of mineralization, and stable isotopic characteristics unequivocally demonstrate that the deposit resulted from high-sulfidation mineralization processes. This unexpected preservation of highsulfidation occurrences opens new perspectives for precious- and base-metal prospecting, not only in the Amazonian Craton, but also in other old cratonic terranes.

The Tapajós high-sulfidation mineral occurrence, which contains magmatic-hydrothermal alunite that gives a ${ }^{40} \mathrm{Ar} /{ }^{39} \mathrm{Ar}$ age of $1.869 \pm 0.002 \mathrm{Ga}$, is related to composite ring volcanoes associated with an inter- preted large ash flow caldera complex. The Tapajós occurrence consists of zones of intense silicification associated with hydrothermal breccia bodies that are covered by a hematite-rich siliceous rock interpreted to be a silica cap. Near the surface, the breccias were affected by strong advanced argillic alteration, represented by pyrophyllite, quartz, pyrite, andalusite, diaspore, rutile, and woodhouseite-svanbergite, which envelopes alunite-rich zones with inner massive or vuggy silica, that characterize strong acid leaching. Ore minerals related to advanced argillic alteration are pyrite, covellite, bornite, enargite-luzonite, galena, chalcopyrite, sphalerite, native silver, copper, and gold. The advanced argillic alteration grades downward and especially outward to intermediate argillic, sericitic, and propylitic alteration. Several generations of alunite occurred over a temperature range from about 130 to $420{ }^{\circ} \mathrm{C}$. The high temperatures indicated by some alunite and pyrite sulfur isotopic fractionations and by alunite $\mathrm{SO}_{4}$ - and $\mathrm{OH}$-site oxygen isotopic fractionations are consistent with the occurrence of andalusite in the alteration assemblages. Limited shearing resulted in local recrystallization and loss of Ar from alunite, but in general the high-sulfidation deposit seems to have been remarkably undisturbed by postmineralization tectonic or supergene events.

\section{Acknowledgments}

We thank Fundação de Amparo à Pesquisa do Estado de São Paulo (grant 98/02567-6), PRONEX/ CNPq/UFPA (662103/1998), and the Conselho Nacional de Pesquisa (CNPq) for the research scholarship granted to Carmen M.D. Nunes. We are grateful to Charles (Skip) Cunningham, Philip M. Bethke, Charles (Chuck) H. Thorman, Robert Seal, Benoît Dubé, and John L. Jambor, who improved the manuscript with constructive reviews. We also thank Cyndi Kester for analyzing samples for stable-isotope compositions and Ross Yeoman for Ar isotopic analyses. In addition, the authors are grateful to José C. Gaspar and Onésio R. Nunes Filho of the Microprobe Laboratory of the Universidade de Brasília, to Marcos de S. Mansueto for support at the Universidade de São Paulo Microprobe Laboratory, and to Rio Tinto Desenvolvimentos Minerais for samples and field-work support. [PD] 


\section{Appendix A. ${ }^{40} \mathrm{Ar} /{ }^{39} \mathrm{Ar}$ data for alunite*}

\begin{tabular}{|c|c|c|c|c|c|c|c|c|}
\hline Temp $\left({ }^{\circ} \mathrm{C}\right)$ & ${ }^{40} \mathrm{Ar}_{\mathrm{R}}$ & ${ }^{39} \mathrm{Ar}_{\mathrm{K}}$ & ${ }^{38} \mathrm{Ar}$ & ${ }^{38} \mathrm{Ar}_{\mathrm{Cl}}{ }^{36} \mathrm{Ar}_{\mathrm{At}}$ & ${ }^{39} \mathrm{Ar}_{\mathrm{K}} /{ }^{36} \mathrm{Ar}_{\mathrm{At}}$ & $\% \operatorname{Rad}$ & $\%^{39} \mathrm{Ar}_{\mathrm{K}}$ & Age \pm erro \\
\hline \multicolumn{9}{|c|}{ X1-16-18, A3-type alunite (first generation), coarse-grained } \\
\hline \multicolumn{9}{|c|}{ Total-gas date: $1843 \pm 2 \mathrm{Ma}$; no plateau; $T_{\max }=1869 \pm 2 \mathrm{Ma} ; J=0.031207,0.1 \%$; weight $9.7 \mathrm{mg}$} \\
\hline 550 & 4.2549 & 0.08103 & 0.00045 & 2.5 & 450 & 98.8 & 4.8 & $1750 \pm 2$ \\
\hline 600 & 0.47634 & 0.0093 & 0.00010 & 2.5 & 231 & 97.3 & 0.5 & $1728 \pm 9$ \\
\hline 650 & 15.145 & 0.27174 & 0.00055 & 5.0 & 2470 & 99.8 & 16.1 & $1818 \pm 2$ \\
\hline 675 & 24.572 & 0.43128 & 0.00125 & 5.7 & 1960 & 99.7 & 25.6 & $1843 \pm 2$ \\
\hline 725 & 47.602 & 0.82307 & 0.00320 & 15.2 & 3922 & 99.9 & 48.8 & $1861 \pm 2$ \\
\hline 775 & 3.8563 & 0.06620 & 0.00046 & 4.2 & 602 & 99.1 & 3.9 & $1869 \pm 2$ \\
\hline 850 & 0.1285 & 0.0023 & 0.00007 & 0.78 & 26 & 82.7 & 0.1 & $1816 \pm 61$ \\
\hline 1300 & 0.0124 & 0.0009 & 0.00007 & 0.44 & 5.4 & 21.0 & 0.1 & $673 \pm 24$ \\
\hline
\end{tabular}

X1-16/G, A3-type alunite (first generation), coarse-grained

Total-gas date: $1848 \pm 2 \mathrm{Ma}$; no plateau; weighted-mean date $=1851 \pm 2 \mathrm{Ma} ; J=0.031368,0.1 \%$; weight $10.3 \mathrm{mg}$

$\begin{array}{lclllllrr}600 & 0.0429 & 0.0023 & 0.00037 & 2.47 & 15.5 & 0.3 & 0.1 & 822 \pm 46 \\ 700 & 55.375 & 0.97529 & 0.00120 & 1.46 & 1189 & 2.1 & 33.1 & 1845 \pm 2 \\ 800^{\mathrm{W}} & 19.291 & 0.33867 & 0.00084 & 5.60 & 2258 & 4.3 & 11.5 & 1849 \pm 2 \\ 850^{\mathrm{W}} & 26.824 & 0.47098 & 0.00110 & 7.86 & 3364 & 3.7 & 16.0 & 1849 \pm 2 \\ 900^{\mathrm{W}} & 11.533 & 0.20219 & 0.00090 & 30.0 & 6740 & 4.0 & 6.9 & 1850 \pm 2 \\ 950^{\mathrm{W}} & 46.561 & 0.81387 & 0.00331 & 66.2 & 16277 & 6.9 & 27.6 & 1854 \pm 2 \\ 1000^{\mathrm{W}} & 7.2928 & 0.12750 & 0.00146 & 48.7 & 4250 & 24.1 & 4.3 & 1854 \pm 2 \\ 1025 & 0.6850 & 0.0134 & 0.00025 & 6.25 & 334 & 12.1 & 0.5 & 1728 \pm 17 \\ 1050 & 0.1504 & 0.0030 & 0.00006 & 0.86 & 4.23 & 3.1 & 0.1 & 1721 \pm 23 \\ 1075 & 0.0150 & 0.0014 & 0.00003 & 1.50 & 71.5 & 2.9 & 0.0 & 514 \pm 6\end{array}$

X1-16/F, As-type alunite (second generation), fine-grained

Total-gas date: $1835 \pm 4 \mathrm{Ma}$; plateau date $=1853 \pm 3 \mathrm{Ma} ; J=0.007257,0.12 \%$; weight $11.3 \mathrm{mg}$

$\begin{array}{lcllllrrr}250 \mathrm{~b} & 0.0091 & 0.0017 & 0.0013 & 0.45 & 0.56 & 1.0 & 0.2 & 70 \pm 8 \\ 300 & 0.0503 & 0.0008 & 0.0001 & 0.16 & 1.20 & 21.1 & 0.1 & 703 \pm 32 \\ 400 & 0.0016 & 0.00006 & 0.00001 & 0.03 & 0.17 & 1.5 & 0.0 & 301 \pm 56 \\ 450 & 0.0012 & 0.00008 & 0.00001 & 0.03 & 0.22 & 1.1 & 0.0 & 197 \pm 30 \\ 450 & 0.0180 & 0.0004 & 0.00002 & 0.05 & 0.81 & 12.4 & 0.0 & 572 \pm 11 \\ 500 & 0.0628 & 0.0006 & 0.00006 & 0.15 & 1.56 & 35.2 & 0.1 & 1011 \pm 59 \\ 550 & 0.3015 & 0.0018 & 0.00005 & 0.13 & 4.66 & 72.9 & 0.2 & 1449 \pm 12 \\ 550 & 1.1762 & 0.0059 & 0.00005 & 0.12 & 13.72 & 90.3 & 0.6 & 1615 \pm 14 \\ 575 & 3.7452 & 0.0167 & 0.00007 & 0.18 & 43.95 & 97.1 & 1.8 & 1743 \pm 5 \\ 600 & 21.728 & 0.09414 & 0.00043 & 0.52 & 115 & 98.9 & 10.4 & 1775 \pm 7 \\ 625 & 1.5509 & 0.00679 & 0.00008 & 0.17 & 14.45 & 91.8 & 0.7 & 1763 \pm 2 \\ 650^{\mathrm{P}} & 48.764 & 0.19753 & 0.00127 & 1.2 & 186 & 99.4 & 21.7 & 1852 \pm 2 \\ 675^{\mathrm{P}} & 71.107 & 0.28732 & 0.00095 & 0.86 & 261 & 99.5 & 31.6 & 1855 \pm 4 \\ 725^{\mathrm{P}} & 71.918 & 0.29140 & 0.00143 & 0.75 & 153 & 99.2 & 32.0 & 1852 \pm 2 \\ 800 & 0.7200 & 0.0031 & 0.00005 & 0.04 & 2.67 & 67.9 & 0.3 & 1794 \pm 14 \\ 950 & 0.0217 & 0.0006 & 0.00003 & 0.03 & 0.63 & 7.8 & 0.1 & 451 \pm 5 \\ 1200 & 0.0030 & 0.0007 & 0.00007 & 0.11 & 1.20 & 1.7 & 0.1 & 53 \pm 9\end{array}$

FV3-1-16, B -type alunite (first generation), medium- to fine-grained; first analysis

Total-gas date: $1820 \pm 11 \mathrm{Ma}$; plateau date $=1834 \pm 3 \mathrm{Ma} ; J=0.007257,0.12 \%$; weight $8.3 \mathrm{mg}$

$\begin{array}{lcllllllr}250 \mathrm{~b} & -0.0005 & 0.00061 & 0.00067 & 0.32 & 0.29 & -0.1 & 0.2 & -12 \pm 80 \\ 450 & 0.0051 & 0.0001 & 0.00004 & 0.57 & 1.86 & 19.9 & 0.0 & 472 \pm 79 \\ 525 & 0.0358 & 0.0002 & 0.00001 & 0.17 & 4.0 & 66.1 & 0.1 & 1374 \pm 31 \\ 600 & 2.9703 & 0.0154 & 0.00003 & 0.38 & 195 & 99.2 & 5.0 & 1623 \pm 9 \\ 675^{\mathrm{P}} & 48.016 & 0.20660 & 0.00000 & \text { nd } & 413 & 99.7 & 67.9 & 1827 \pm 9\end{array}$


Appendix A (continued)

\begin{tabular}{|c|c|c|c|c|c|c|c|c|}
\hline Temp $\left({ }^{\circ} \mathrm{C}\right)$ & ${ }^{40} \mathrm{Ar}_{\mathrm{R}}$ & ${ }^{39} \mathrm{Ar}_{\mathrm{K}}$ & ${ }^{38} \mathrm{Ar}$ & ${ }^{38} \mathrm{Ar}_{\mathrm{Cl}}{ }^{36} \mathrm{Ar}_{\mathrm{At}}$ & ${ }^{39} \mathrm{Ar}_{\mathrm{K}} /{ }^{36} \mathrm{Ar}_{\mathrm{At}}$ & $\% \operatorname{Rad}$ & $\%^{39} \mathrm{Ar}_{\mathrm{K}}$ & Age \pm error $(\mathrm{Ma})$ \\
\hline $700^{P}$ & 16.450 & 0.0694 & 0.00016 & 2.29 & 992 & 99.9 & 22.8 & $1850 \pm 15$ \\
\hline $725^{\mathrm{P}}$ & 2.1660 & 0.0091 & 0.00000 & nd & 101 & 98.8 & 3.0 & $1853 \pm 26$ \\
\hline 750 & 0.2368 & 0.0010 & 0.00002 & 1.0 & 52 & 97.7 & 0.3 & $1804 \pm 21$ \\
\hline 800 & 0.3434 & 0.0017 & 0.00000 & nd & 16.8 & 91.9 & 0.6 & $1682 \pm 11$ \\
\hline 950 & 0.0118 & 0.0004 & 0.00003 & 0.60 & 7.2 & 42.2 & 0.1 & $398 \pm 81$ \\
\hline 1150 & 0.0250 & 0.0003 & 0.00002 & 0.33 & 5.5 & 57.7 & 0.1 & $818 \pm 96$ \\
\hline 1350 & 0.0419 & 0.0002 & 0.00001 & 0.01 & 0.19 & 13.5 & 0.1 & $1883 \pm 30$ \\
\hline
\end{tabular}

FV3-1-16, B-type alunite (first generation), medium- to fine-grained; second analysis

Total-gas date: $1808 \pm 2 \mathrm{Ma}$; plateau date $=1846 \pm 2 \mathrm{Ma} ; J=0.031319,0.1 \%$; weight $10.4 \mathrm{mg}$

$\begin{array}{lclllllll}500 & 11.063 & 0.23061 & 0.00084 & 1.68 & 461 & 98.7 & 14.3 & 1655 \pm 2 \\ 550 & 9.8095 & 0.18067 & 0.00024 & 3.00 & 2258 & 99.8 & 11.2 & 1792 \pm 2 \\ 575 & 10.154 & 0.18280 & 0.00035 & 8.75 & 4570 & 99.9 & 11.3 & 1818 \pm 2 \\ 600^{\mathrm{P}} & 53.307 & 0.93741 & 0.00143 & 4.90 & 3232 & 99.8 & 58.0 & 1845 \pm 2 \\ 625^{\mathrm{P}} & 3.6651 & 0.06420 & 0.00033 & 2.54 & 494 & 99.0 & 4.0 & 1850 \pm 2 \\ 650 & 0.5555 & 0.0102 & 0.00015 & 5.00 & 340 & 98.5 & 0.6 & 1796 \pm 14 \\ 675 & 0.1151 & 0.0021 & 0.00004 & 4.00 & 212 & 96.5 & 0.1 & 1794 \pm 13 \\ 700 & 0.1297 & 0.0025 & 0.00006 & 6.00 & 252 & 96.9 & 0.2 & 1734 \pm 14 \\ 750 & 0.1248 & 0.0028 & 0.00008 & 1.60 & 56 & 89.2 & 0.2 & 1580 \pm 15 \\ 1000 & 0.0146 & 0.0034 & 0.00010 & 1.67 & 57 & 46.9 & 0.2 & 227 \pm 42\end{array}$

FV3-1-11, B 1 -type alunite (first generation), fine-grained cement

Total-gas date: $1842 \pm 2 \mathrm{Ma}$; weighted-mean date $=1867 \pm 2 \mathrm{Ma} ; J=0.029713,0.1 \%$; weight $11.6 \mathrm{mg}$

$\begin{array}{lcllllllr}250 \mathrm{~b} & 0.0632 & 0.0056 & 0.00358 & 0.71 & 1.10 & 4.1 & 0.1 & 523 \pm 13 \\ 400 & 0.0346 & 0.0018 & 0.00008 & 0.12 & 2.72 & 14.6 & 0.0 & 798 \pm 31 \\ 500 & 0.36830 & 0.0093 & 0.00007 & 0.14 & 19.3 & 72.2 & 0.2 & 1408 \pm 3 \\ 550 & 6.0797 & 0.1549 & 0.00179 & 1.90 & 165 & 95.6 & 3.4 & 1395 \pm 12 \\ 575 & 29.146 & 0.50582 & 0.00163 & 2.91 & 903 & 99.4 & 11.0 & 1800 \pm 2 \\ 600 & 4.0921 & 0.06904 & 0.00020 & 0.30 & 103 & 95.4 & 1.5 & 1832 \pm 2 \\ 625^{\mathrm{W}} & 14.73 & 2.3243 & 0.00824 & 6.87 & 1937 & 99.7 & 50.5 & 1865 \pm 2 \\ 650^{\mathrm{W}} & 2.8361 & 0.04676 & 0.00018 & 0.11 & 28.1 & 85.2 & 1.0 & 1859 \pm 2 \\ 675^{\mathrm{W}} & 88.623 & 1.4466 & 0.00537 & 3.03 & 817 & 99.4 & 31.4 & 1871 \pm 2 \\ 700^{\mathrm{W}} & 1.9878 & 0.0326 & 0.00024 & 0.67 & 90.7 & 94.9 & 0.7 & 1863 \pm 4 \\ 725 & 0.1046 & 0.0021 & 0.00003 & 0.06 & 3.96 & 40.0 & 0.0 & 1638 \pm 23 \\ 800 & 0.0041 & 0.0003 & 0.00005 & 0.07 & 2.52 & 1.9 & 0.0 & 643 \pm 43 \\ 1200 & 0.0019 & 0.0007 & 0.00005 & 0.07 & 0.92 & 0.9 & 0.0 & 143 \pm 23\end{array}$

FV3-2-7, $B_{2}$-type alunite (second generation), coarse-grained

Total-gas date: $1828 \pm 2 \mathrm{Ma}$; no plateau; $T_{\max }=1857 \pm 2 \mathrm{Ma} ; J=0.031300,0.1 \%$; weight $11.7 \mathrm{mg}$

$\begin{array}{lclllllll}500 & 0.1026 & 0.0023 & 0.00032 & 2.13 & 15.3 & 69.4 & 0.1 & 1579 \pm 29 \\ 550 & 13.234 & 0.25955 & 0.00063 & 3.32 & 1366 & 99.6 & 11.1 & 1721 \pm 3 \\ 600 & 62.696 & 1.11194 & 0.00020 & 20 & 111000 & 99.9 & 47.4 & 1835 \pm 2 \\ 650 & 48.138 & 0.84323 & 0.00118 & 5.90 & 4216 & 99.9 & 35.9 & 1849 \pm 2 \\ 675 & 3.5697 & 0.0623 & 0.00014 & 2.80 & 1246 & 99.6 & 2.7 & 1853 \pm 5 \\ 700 & 3.436 & 0.05975 & 0.00013 & 1.62 & 747 & 99.3 & 2.5 & 1857 \pm 2 \\ 800 & 0.4113 & 0.0077 & 0.00005 & 0.71 & 110 & 95.0 & 0.3 & 1771 \pm 10 \\ 1250 & 0.0290 & 0.0013 & 0.00008 & 4.00 & 67.0 & 84.2 & 0.1 & 932 \pm 91\end{array}$

FV3-1-25, B3-type alunite (third generation), coarse-grained

Total-gas date: $1842 \pm 2 \mathrm{Ma}$; plateau date $=1858 \pm 2 \mathrm{Ma} ; J=0.031310,0.1 \%$; weight $9.9 \mathrm{mg}$

\begin{tabular}{rllllllll}
500 & 0.0437 & 0.0011 & 0.00035 & 3.89 & 5.95 & 43.4 & 0.0 & $1434 \pm 33$ \\
550 & 1.5847 & 0.03564 & 0.00027 & 3.86 & 509 & 98.6 & 1.5 & $1574 \pm 3$ \\
575 & 35.587 & 0.63959 & 0.00040 & 2.22 & 3553 & 99.8 & 27.3 & $1820 \pm 2$ \\
\hline
\end{tabular}


Appendix A (continued)

\begin{tabular}{lclllllll}
\hline Temp $\left({ }^{\circ} \mathrm{C}\right)$ & ${ }^{40} \mathrm{Ar}_{\mathrm{R}}$ & ${ }^{39} \mathrm{Ar}_{\mathrm{K}}$ & ${ }^{38} \mathrm{Ar}_{\mathrm{Cl}}$ & ${ }^{38} \mathrm{Ar}_{\mathrm{Cl}}{ }^{36} \mathrm{Ar}_{\mathrm{At}}$ & ${ }^{39} \mathrm{Ar}_{\mathrm{K}} /{ }^{36} \mathrm{Ar}_{\mathrm{At}}$ & ${ }^{\%} \mathrm{Rad}$ & ${ }^{\% 9} \mathrm{Ar}_{\mathrm{K}}$ & $\mathrm{Age}^{3} \mathrm{error}(\mathrm{Ma})$ \\
\hline 600 & 10.867 & 0.19055 & 0.00005 & 0.83 & 3176 & 99.8 & 8.1 & $1848 \pm 2$ \\
625 & 0.2147 & 0.0038 & 0.00004 & 2.00 & 190 & 97.7 & 0.2 & $1838 \pm 16$ \\
$650^{\mathrm{P}}$ & 17.616 & 0.30732 & 0.00048 & 9.60 & 6146 & 99.9 & 13.1 & $1854 \pm 3$ \\
$675^{\mathrm{P}}$ & 64.373 & 1.1186 & 0.00237 & 39.5 & 18643 & 99.9 & 47.4 & $1859 \pm 2$ \\
$700^{\mathrm{P}}$ & 2.456 & 0.04256 & 0.00014 & 2.80 & 851 & 99.4 & 1.8 & $1862 \pm 4$ \\
750 & 0.2786 & 0.0051 & 0.00007 & 0.64 & 46.3 & 89.6 & 0.2 & $1800 \pm 13$ \\
1000 & 0.0745 & 0.0020 & 0.00009 & 1.00 & 22.2 & 74.5 & 0.1 & $1394 \pm 16$
\end{tabular}

FV3-1-12, Alunite, fine-grained, recrystallized in small shear zone

Total-gas date: $1712 \pm 2 \mathrm{Ma}$; no plateau; $T_{\max }=1805 \pm 2 \mathrm{Ma} ; J=0.030540,0.1 \%$; weight $9.6 \mathrm{mg}$

$\begin{array}{lllllllll}450 & 0.0196 & 0.0009 & 0.00006 & 0.38 & 5.44 & 29.8 & 0.0 & 948 \pm 15 \\ 525 & 0.0334 & 0.0014 & 0.00005 & 0.62 & 17.5 & 57.5 & 0.1 & 984 \pm 46 \\ 550 & 1.2173 & 0.04009 & 0.00006 & 1.50 & 1002 & 98.9 & 1.9 & 1184 \pm 1 \\ 600 & 32.469 & 0.67332 & 0.00027 & 3.86 & 9619 & 99.9 & 32.7 & 1633 \pm 2 \\ 625 & 66.445 & 1.2228 & 0.00046 & 1.92 & 5095 & 99.9 & 59.4 & 1765 \pm 2 \\ 650 & 4.0219 & 0.07140 & 0.00003 & 0.43 & 1020 & 99.5 & 3.5 & 1805 \pm 2 \\ 675 & 2.1886 & 0.03902 & 0.00008 & 1.60 & 780 & 99.3 & 1.9 & 1800 \pm 2 \\ 800 & 0.3920 & 0.0074 & 0.00009 & 0.82 & 67.8 & 92.3 & 0.4 & 1728 \pm 7 \\ 1200 & 0.0160 & 0.0036 & 0.00013 & 1.44 & 39.7 & 36.6 & 0.2 & 231 \pm 9\end{array}$

FV3-3-3, Alunite, fine-grained, supergene

Total-gas date: $99.4 \pm 0.4 \mathrm{Ma}$; weighted-mean date $=51.3 \pm 0.1 \mathrm{Ma} ; J=0.031170,0.1 \%$; weight $11.9 \mathrm{mg}$

$\begin{array}{llllllllr}400 & 0.0023 & 0.0005 & 0.00014 & 2.0 & 7.0 & 10.4 & 0.0 & 244 \pm 62 \\ 450 & 0.0334 & 0.0059 & 0.00029 & 1.4 & 28 & 34.5 & 0.2 & 293 \pm 15 \\ 500 & 0.0505 & 0.0182 & 0.00014 & 2.8 & 363 & 77.0 & 0.7 & 150 \pm 12 \\ 525 & 0.10659 & 0.08247 & 0.00006 & 1.0 & 1374 & 84.3 & 3.0 & 71 \pm 2 \\ 550 & 0.46165 & 0.47654 & \text { bd } & \text { bd } & 5295 & 93.8 & 17.5 & 53.7 \pm 0.1 \\ 575^{\mathrm{W}} & 0.50682 & 0.54896 & \text { bd } & \text { bd } & 13724 & 96.9 & 20.1 & 51.2 \pm 0.1 \\ 600^{\mathrm{W}} & 0.66374 & 0.71565 & \text { bd } & \text { bd } & 23855 & 97.6 & 26.2 & 51.4 \pm 0.1 \\ 625 & 1.0437 & 0.82427 & \text { bd } & \text { bd } & 9159 & 96.8 & 30.2 & 69.8 \pm 0.3 \\ 650 & 0.0992 & 0.0073 & 0.00004 & 1.0 & 183 & 89.9 & 0.3 & 636 \pm 3 \\ 700 & 0.3797 & 0.0110 & 0.00010 & 3.3 & 366 & 97.4 & 0.4 & 1320 \pm 7 \\ 1000 & 1.6138 & 0.03995 & 0.00033 & 1.9 & 235 & 92.3 & 1.5 & 1470 \pm 2\end{array}$

${ }^{+}$Abundance of ${ }^{40} \mathrm{Ar}_{\mathrm{R}}$ (radiogenic ${ }^{40} \mathrm{Ar}$ ), ${ }^{39} \mathrm{Ar}_{\mathrm{K}}$ (K-derived ${ }^{39} \mathrm{Ar}$ ), and ${ }^{38} \mathrm{Ar}_{\mathrm{Cl}}$ (Cl-derived ${ }^{38} \mathrm{Ar}$ ) is measured in volts and calculated to five decimal places. Voltage may be converted to moles using $1.160 \times 10^{-12} \mathrm{~mol}$ Ar per volt signal. The " $F$ " value can be directly calculated from the data on the table. All isotopic abundances were corrected for mass discrimination by calculating the ${ }^{40} \mathrm{Ar} /{ }^{36} \mathrm{Ar}$ ratio of aliquants of atmospheric Ar pipetted from a fixed pipette on the extraction line; the ratio during this experiment was 298.9, which was corrected to 295.5 to account for mass discrimination. Final isotopic abundances were corrected for all interfering isotopes of Ar including atmospheric Ar. The ${ }^{37} \mathrm{Ar}$ and ${ }^{39} \mathrm{Ar}$, which are produced during irradiation, are radioactive and their abundances were corrected for radioactive decay. Abundances of interfering isotopes from $\mathrm{K}$ and $\mathrm{Ca}$ were calculated from reactor production ratios determined by irradiating and analyzing pure $\mathrm{CaF}_{2}$ and $\mathrm{K}_{2} \mathrm{SO}_{4}$; the $\mathrm{K}_{2} \mathrm{SO}_{4}$ was degassed in a vacuum furnace prior to irradiation to release extraneous Ar. Corrections for Cl-derived ${ }^{36} \mathrm{Ar}$ were determined using the method of Roddick (1983). Production ratios for this experiment are available in Snee (2002).

${ }^{@}$ Apparent ages and associated errors were calculated from analytical data, then rounded using associated analytical errors. Apparent ages of each fraction include the error in $J$ value $(0.1 \%)$, which was calculated from the reproducibility of splits of the Ar from several standards. Apparent ages were calculated using decay constants of Steiger and Jäger (1977). All apparent age errors are cited at 1 sigma. Uncertainties in the calculations for apparent age of individual fractions were calculated using the equations of Dalrymple et al. (1981).

${ }^{\mathrm{p}}$ Fraction included in plateau date. Plateaus determined according to the method of Fleck et al. (1977).

${ }^{\mathrm{W}}$ Fraction included in weighted-mean date.

* Alunite (99\% pure) was picked from vein material collected from three surface samples ( $X$ numbers) and from six drill-core samples (FV numbers). Each alunite was ground to $250-125 \mu \mathrm{m}$ and cleaned with reagent-grade acetone, alcohol, and deionized water and air-dried. Eight to $12 \mathrm{mg}$ of each alunite was wrapped in an $\mathrm{Al}$ foil. Two aliquants of alunite, FV3-1-16, were irradiated in two different irradiation packages and analyzed twice. Seven of the 10 samples were encapsulated in silica-glass vials with other samples and flux standards adjacent to each unknown. Three of the 10 samples were each encapsulated alone in "break-seal" silica-glass vials and evacuated to better than $10^{-8}$ torr; for these 3 , the neutron-flux standards were enclosed in adjacent silica vials. One of the two aliquants of sample FV3-1-16 was irradiated in a "break-seal" vial; 


\section{References}

Almeida, M.E., Brito, M.F.L., Ferreira, A.L., Monteiro, M.A.S., 2000. Geologia e recursos minerais da Folha Mamãe Anã (SB.21-V-D). Estados do Amazonas e Pará. Escala 1:250.000. PROMIN Tapajós, CPRM, Brasília, Brazil (CD-ROM).

Andrew, C.J., 2002. The Chelopech Au deposit, Bulgaria. http:// www.huxley.ic.ac.uk/research/basins/wilkinson/mdsg/webpages/ mdsgabs/andrew $\sim 1 . h t m$.

Arribas Jr., A., 1995. Characteristics of high-sulfidation epithermal deposits, and their relation to magmatic fluid. In: Thompson, J.F.H. (Ed.), Magmas, Fluids, and Ore Deposits, Mineral. Assoc. Can. Short Course vol. 23, pp. 419-454.

Arribas Jr., A., Cunningham, C.G., Rytuba, J.J., Rye, R.O., Kelly, W.C., Podwysocki, M.H., et al., 1995. Geology, geochronology, fluid inclusions, and isotope geochemistry of the Rodalquilar gold alunite deposit, Spain. Econ. Geol. 90, 795-822.

Ayuso, R.A., Wooden, J.L., Foley, N.K., Seal, R.R., Sinha, A.K., Persing, H., In press. U-Pb zircon (SHRIMP-RG) ages and $\mathrm{Pb}$ isotope geochemistry of gold deposits in the Carolina Slate Belt. Econ. Geol.

Bahia, R.B.C., Quadros, M.L.E.S., 2000. Geologia e recursos minerais da Folha Caracol (SB.21-X-C). Estado do Pará. Escala 1:250.000. PROMIN Tapajós, CPRM, Brasília, Brazil (CD-ROM).

Bethke, P.M., Rye, R.O., Stoffregen, R.E., Vikre, P., 2005. Evolution of the magmatic-hydrothermal acid-sulfate system at Summitville, Colorado: integration of geological, stableisotope, and fluid-inclusion evidence. Chem. Geol. 215, 281315 (this volume).

Bezerra, P.E.L., 1984. Cronoestratigrafia das coberturas sedimentares proterozóicas do Cráton Amazônico e seu relacionamento com o Supergrupo Uatumã (Amazônia Legal). 33th Congr. Bras. Geol., SBG/RJ, Rio de Janeiro, Brazil, Anais, vol. 5, pp. $2125-2139$.

Casadevall, T., Rye, R.O., 1980. The Tungsten Queen deposit, Hamme district, Vance County, North Carolina: a stable isotope study of a metamorphosed quartz-huebnerite vein. Econ. Geol. 75, 523-537.

Corrêa-Silva, R.H., Juliani, C., Nunes, C.D.M., 2000. Hydrothermal alteration gold mineralizations in rapakivi-like granite from Garimpo do Batalha, Tapajós Province, Amazon Craton, Brazil. $31^{\text {st }}$ Int. Geol. Congr. IUGS/CPRM, Rio de Janeiro, Brazil, Abs. (CD-ROM).

Craig, H., 1961. Isotopic variations in meteoric waters. Science 133, $1702-1703$.

Dall'Agnol, R., Lafon, J.M., Macambira, M.J.B., 1994. Proterozoic anorogenic magmatism in the Central Amazonian Craton: geochronological and geochemical aspects. Mineral. Petrol. 50, $113-138$.

Dall'Agnol, R., da Silva, C.M.G., Scheller, T., 1999. Fayalitehedenbergite rhyolites of Iriri Formation, Tapajós Gold Province, Amazonian Cráton: implications for the Uatumã volcanism. $1^{\text {st }}$ Simp. Vulc. Amb. Assoc., SBG, Gramado, Brazil, Bol. Res., pp. 31.

Dalrymple, G.B., Clague, D.A., Garcia, M.O., Bright, S.W., 1981. Petrology and $\mathrm{K}-\mathrm{Ar}$ of dredged samples from Laysan Island and Northampton Bank volcanoes, Hawaiian Ridge, and evolution of the Hawaiian-Emperor chain. Geol. Soc. Amer. Bull. 92 (I315-I318), II884-II933.

Davidson, J., Mpodozis, C., 1991. Regional geologic settings of epithermal gold deposits, Chile. Econ. Geol. 86, 1174-1186.

de Almeida, F.F.M., Hasui, Y., de B. Neves, B.B., Fuck, R.A., 1981. Brazilian structural provinces: an introduction. Earth-Sci. Rev. $17,1-29$.

Deen, J.A., 1990. Hydrothermal ore deposition related to high-level igneous activity: a stable-isotopic study of the Julcani mining district, Peru. PhD thesis, Univ. Colorado, Boulder.

Deyell, C.L., Thompson, J.F.H., Friedman, R.M., Groat, L.A., 2000. Age and origin of advanced argillic alteration zones and related exotic limonite deposits in the Limonite Creek area, British Columbia. Can. J. Earth Sci. 37, 1093-1107.

Deyell, C., Rye, R.O., Landis, G.P., Bissig, T., 2005. Alunite and the role of magmatic fluids in the Tambo high-sulfidation deposit, El Indio-Pascua belt, Chile. Chem. Geol. 215, 185218 (this volume).

Dubé, B., Dunning, G., Lauzière, K., 1998. Geology of the Hope Brook mine, Newfoundland, Canada: a preserved late Proterozoic high-sulfidation epithermal gold deposit and its implications for exploration. Econ. Geol. 93, 405-436.

Faraco, M.T.L., Carvalho, J.M. de A., Klein, E.L., 1997. Carta metalogenética da Província Aurífera do Tapajós. In: Costa, M.L., Angélica R.S. da (Coords.), Contribuições à Geologia da Amazônia. FINEP-SBG/N, Belém, Brazil, pp. 423-437.

\footnotetext{
Notes to Appendix A (continued):

the other was irradiated the other way. The standard for this experiment is hornblende MMhb- 1 with percent $\mathrm{K}=1.555,{ }^{40} \mathrm{Ar}_{\mathrm{R}}=1.624 \times 10^{-9} \mathrm{~mol}$ $\mathrm{g}^{-1}$ (Samson and Alexander, 1987), and $\mathrm{K}-\mathrm{Ar}$ age $=523.1 \pm 2.6 \mathrm{Ma}$ (Renne et al., 1998). For irradiation, an aluminum canister was loaded with the silica vials and irradiated in three different irradiation packages; one contained FV3-1-16 in a "break-seal" vial, and it was irradiated for 30 $\mathrm{h}$ in the TRIGA reactor at the U.S.G.S. in Denver, CO. Subsequently, eight additional alunite samples were irradiated for $129 \mathrm{~h}$ in a second package to acquire more optimal ${ }^{40} \mathrm{Ar}_{\mathrm{R}}{ }^{39} \mathrm{Ar}_{\mathrm{K}}$ ratios. This second package also contained a "break-seal" vial. A third irradiation for $30 \mathrm{~h}$ contained one alunite sample in a "break-seal" vial. The alunite and standards were analyzed in the Denver Argon Laboratory of the U.S.G.S. using a Mass Analyser Products 215 rare-gas mass spectrometer on a Faraday-cup collector. The vacuum-encapsulated vials were loaded into the extraction system and baked at $250{ }^{\circ} \mathrm{C}$ before the vacuum seal was broken on line, and the released gas was analyzed to determine whether any Ar had been recoiled from the sample during irradiation. These analyzed fractions are indicated as the 250b step in the above table. All alunite samples were heated in a double-vacuum low-blank resistance furnace for $20 \mathrm{~min}$, in a series of 8 to 17 steps, to a maximum of $1350{ }^{\circ} \mathrm{C}$, and analyzed using the standard stepwise heating technique described by Snee (2002). Each standard was degassed to release Ar in a single step at $1250{ }^{\circ} \mathrm{C}$. For every Ar measurement, ${ }^{40} \mathrm{Ar},{ }^{39} \mathrm{Ar},{ }^{38} \mathrm{Ar},{ }^{37} \mathrm{Ar}$, and ${ }^{36} \mathrm{Ar}$ are measured. Detection limit was $2 \times 10^{-17} \mathrm{~mol}$ of $\mathrm{Ar}$.
} 
Ferreira, A.L., Almeida, M.E., Brito, M.F.L., Monteiro, M.A.S., 2000. Geologia e recursos minerais da Folha Jacareacanga (SB.21-Y-B), Estados do Amazonas e Pará. Escala 1:250.000. PROMIN Tapajós, CPRM, Manaus, Brazil (CD-ROM).

Fifarek, R.H., Rye, R.O., 2005. Stable-isotope geochemistry of the Pierina high-sulfidation $\mathrm{Au}-\mathrm{Ag}$ deposit, Peru: influence of hydrodynamics on $\mathrm{SO}_{4}^{2-}-\mathrm{H}_{2} \mathrm{~S}$ isotopic exchange in magmaticsteam and steam-heated deposits. Chem. Geol. 215, 253-279 (this volume).

Fleck, R.J., Sutter, J.F., Elliot, D.H., 1977. Interpretation of discordant ${ }^{40} \mathrm{Ar} /{ }^{39} \mathrm{Ar}$ age spectra of Mesozoic tholeiites from Antarctica. Geochim. Cosmochim. Acta 41, 15-32.

Fournier, R.O., 1999. Hydrothermal processes related to movement of fluid from plastic into brittle rock in the magmatichydrothermal environment. Econ. Geol. 94, 1193-1212.

Giggenbach, W.F., 1997. The origin and evolution of fluids in magmatic-hydrothermal systems. In: Barnes, H.L. (Ed.), Geochemistry of Hydrothermal Ore Deposits, $3^{\text {rd }}$ ed. Wiley, New York, pp. 737-796.

Hallberg, A., 1994. The Enåesen gold deposit, central Sweden. 1: a Palaeoproterozoic high-sulphidation epithermal gold mineralization. Miner. Depos. 29, 150-162.

Harvey, B.A., Myers, S.A., Klein, T., 1999. Yanacocha gold district, northern Peru. In: Weber, G. (Ed.), PACRIM '99, Australiasian Inst. Mining Metall. Pub. Ser., vol. 4/99, pp. 445-458.

Hedenquist, J.W., Lowenstern, J.B., 1994. The role of magmas in the formation of hydrothermal ore deposits. Nature 370 , $519-527$.

Hedenquist, J.W., Arribas Jr., A., Reynolds, T.J., 1998. Evolution of an intrusion-centered hydrothermal system: far SoutheastLepanto porphyry and epithermal $\mathrm{Cu}-\mathrm{Au}$ deposits, Philippines. Econ. Geol. 93, 373-404.

Hedenquist, J.W., Arribas Jr., A., Gonzalez-Urien, E., 2000. Exploration for epithermal gold deposits. In: Hagemann, S.G., Brown, P.E. (Eds.), Gold in 2000, Rev. Econ. Geol., vol. 13, pp. $245-277$.

Hemley, J.J., Montoya, J.W., Marinenko, J.W., Luce, R.W., 1980. Equilibria in the system $\mathrm{Al}_{2} \mathrm{O}_{3}-\mathrm{SiO}_{2}-\mathrm{H}_{2} \mathrm{O}$ and some general implications for alteration/mineralization processes. Econ. Geol. $75,210-228$.

Jacobi, P., 1999. The discovery of epithermal $\mathrm{Au}-\mathrm{Cu}-\mathrm{Mo}$ Proterozoic deposits in the Tapajós Province, Brazil. Rev. Bras. Geocienc. 29, 277-279.

Jambor, J.L., 1999. Nomenclature of the alunite supergroup. Can. Mineral. 37, 1323-1341.

Juliani, C., Nunes, C.D.N., Bettencourt, J.S., Corrêa-Silva, R.H., Monteiro, L.V.S., Neumann, R., et al., 2000. Early Proterozoic volcanic-hosted quartz-alunite epithermal deposits in the Tapajós gold province, Amazonian Craton, Brazil. Abstr. Programs - Geol. Soc. Am. 32(7), A-49.

Juliani, C., Corrêa-Silva, R.H., Monteiro, L.V.S., Bettencourt, J.S., Nunes, C.M.D., 2002. The Au-granite Batalha system-Tapajós Gold Province, Amazonian Craton, Brazil: hydrothermal alteration and regional implications. Precambrian Res. 119, $225-256$.

Juliani, C., Corrêa-Silva, R.H., Monteiro, L.V.S., Bettencourt, J.S., Dall'Agnol, R., 2003. Epithermal and plutonic gold mineralizations related to Paleoproterozoic acid magmatism in the Tapajós gold province, Amazonian Craton, Brazil. EGS-AGU-EUG Joint Assembly. Geophys. Res. Abstr. 5, 14239 (CD-ROM).

Klein, E.L., Vasquez, M.L., 2000. Geologia e recursos minerais da Folha Vila Riozinho (SB.21-Z-A). Estado do Pará. Escala 1:250.000. PROMIN Tapajós, CPRM, Brasília, Brazil (CDROM).

Koukharsky, M., Mirre, J.C., 1976. Mi Vida prospect: a porphyry copper-type deposit in northwestern Argentina. Econ. Geol. 71, $849-863$

Lamarão, C.N., Dall'Agnol, R., Lafon, J.-M., Lima, E.F., 2002. Geology, geochemistry, and $\mathrm{Pb}-\mathrm{Pb}$ zircon geochronology of the Paleoproterozoic magmatism of Vila Riozinho, Tapajós Gold Province, Amazonian craton, Brazil. Precambrian Res. 119, 189-223.

Landis, G.P., Snee, L.W., Juliani, C., 2005. Evaluation of alunite argon ages and fluid-inclusion integrity: stepped noble-gas heating experiments on $1.87 \mathrm{Ga}$ alunite from Tapajós gold province, Brazil. Chem. Geol. 215, 127-153 (this volume).

Lu, C., Misra, K.C., Stonehouse, J.M., Zwaschka, M.R., 1992. Geochemical signature of alteration at the Brewer gold mine, Jefferson, South Carolina. S C. Geol. 35, 37-54.

Motta, P.S., Jimenez-Rueda, J.R., Leite Jr., W.B., Payolla, B.L., Muzzolon, R., Bettencourt, J.S., 2000. Caracterização das coberturas de alteração intempérica na região da Mina Bom Futuro, Rondônia: considerações preliminares. $12^{\text {th }}$ Cong. Iniciação Científica, UNESP, São José do Rio Preto, Brazil, pp. 149.

Nelson, C.E., 2000. Volcanic domes and gold mineralization in the Pueblo Viejo district, Dominican Republic. Miner. Depos. 35, $511-525$.

Nunes, C.M.D., Juliani, C., Corrêa-Silva, R.H., Bettencourt, J.S., Jacobi, P., 2000. Paleoproterozoic quartz-alunite epithermal gold mineralization from Tapajós (Brazil). $31^{\text {st }}$ Int. Geol. Congr., IUGS/CPRM, Rio de Janeiro, Brazil, Abs. (CD-ROM).

Ohmoto, H., Lasaga, A.C., 1982. Kinetics of reactions between aqueous sulfates and sulfides in hydrothermal systems. Geochim. Cosmochim. Acta 46, 1727-1746.

Ohmoto, H., Rye, R.O., 1979. Isotopes of sulfur and carbon. In: Barnes, H.L. (Ed.), Geochemistry of Hydrothermal Ore deposits, $2^{\text {nd }}$ ed. Wiley, New York, pp. 509-567.

Quadros, M.L.E.S., Bahia, R.B.C., Klein, E.L., Vasquez, M.L., Almeida, M.E., Ricci, P.S.F., et al., 1999. As intrusões básicas da Província Mineral do Tapajós (PMT) e possibilidades de mineralizações associadas. $6^{\text {th }}$ Simp. Geol. Amazônia, Manaus, Brazil, SBG/N, Anais, pp. 567-569.

Renne, P.R., Swisher, C.C., Deino, A.L., Karner, D.B., Owens, T.L., DePaolo, D.J., 1998. Intercalibration of standards, absolute ages and uncertainties in ${ }^{40} \mathrm{Ar} /{ }^{39} \mathrm{Ar}$ dating. Chem. Geol. 145, 117-152.

Ricci, P.S.F., dos Santos, A., Klein, E.L., João, X.S.J., Martins, R.C., 1999. Suíte Intrusiva Creporizão-Província Tapajós: Proposta e critérios de definição. $6^{\text {th }}$ Simp. Geol. Amazônia, Manaus, SBG/N, Anais, pp. 519-522.

Roddick, J.C., 1983. High precision intercalibration of ${ }^{40} \mathrm{Ar}-{ }^{39} \mathrm{Ar}$ standards. Geochim. Cosmochim. Acta 47, 887-898. 
Rye, R.O., 1993. The evolution of magmatic fluids in the epithermal environment: the stable isotope perspective. Econ. Geol. 88, $733-753$.

Rye, R.O., 2005. A review of the stable-isotope geochemistry of sulfate minerals in selected environments and related hydrothermal systems. Chem. Geol. 215, 5-36 (this volume).

Rye, R.O., Stoffregen, R.E., Bethke, P.M., 1990. Stable isotope systematics and magmatic hydrothermal processes in the Summitville, CO, gold deposit. Open-File Rep. (U. S. Geol. Surv.), 90-626.

Rye, R.O., Bethke, P.M., Wasserman, M.D., 1992. The stable isotope geochemistry of acid sulfate alteration. Econ. Geol. 87, $225-262$.

Samson, S.D., Alexander, E.C., 1987. Calibration of interlaboratory ${ }^{40} \mathrm{Ar} /{ }^{39} \mathrm{Ar}$ dating standard, MMhb-1. Isot. Geosci. 66, $27-34$.

Santos, J.O.S., Hartmann, L.A., Gaudette, H.E., Groves, D.I., McNaughton, N.J., Fletcher, I.R., 2000. A new understanding of the provinces of Amazon Craton based on integration of field mapping and $\mathrm{U}-\mathrm{Pb}$ and $\mathrm{Sm}-\mathrm{Nd}$ geochronology. Gondwana Res. 3, 453-488.

Santos, J.O.S., Groves, D.I., Hartmann, L.A., Moura, M.A., McNaughton, N.J., 2001. Gold deposits of the Tapajós and Alta Floresta domains, Tapajós-Parima orogenic belt, Amazon Craton, Brazil. Miner. Depos. 36, 453-488.

Savin, S.M., Epstein, S., 1970. The oxygen and hydrogen isotope geochemistry of clay minerals. Geochim. Cosmochim. Acta 34, $24-42$.

Seal II, R.R., Ayuso, R.A., Foley, N.K., Clark, S.H.B., 2001. Sulfur isotope geochemistry of hypogene mineralization at the Barite Hill gold deposit, S.C.: a window into and through regional metamorphism. Miner. Depos. 36, 137-148.

Sillitoe, R.H., 1973. The tops and bottoms of porphyry copper deposits. Econ. Geol. 68, 799-815.

Sillitoe, R.H., 1991. Gold metallogeny of Chile-an introduction. Econ. Geol. 86, 1187-1205.

Snee, L.W., 2002. Argon thermochronology of mineral deposits-a review of analytical methods, formulations, and selected applications. U.S. Geol. Surv. Bull. B2194.

So, C.-S., Zhang, D.-Q., Yun, S.-T., Li, D.-X., 1998. Alterationmineralization zoning and fluid inclusions of the high sulfidation epithermal $\mathrm{Cu}-\mathrm{Au}$ mineralization at Zijinshan, Fujian Province, China. Econ. Geol. 93, 961-980.
Steiger, R.H., Jäger, E., 1977. Subcommission on geochronology: convention on the use of decay constants in geo- and cosmochronology. Earth Planet. Sci. Lett. 36, 359-362.

Stoffregen, R.E., 1987. Genesis of acid-sulfate alteration and Au$\mathrm{Cu}-\mathrm{Ag}$ mineralization at Summitville, Colorado. Econ. Geol. 82, 1575-1591.

Stoffregen, R.E., Alpers, C.N., 1987. Woodhouseite and svanbergite in hydrothermal ore deposits: products of apatite destruction during advanced argillic alteration. Can. Mineral. 25, 201-212.

Stoffregen, R.E., Cygan, G.L., 1990. An experimental study of Na$\mathrm{K}$ exchange between alunite and aqueous sulfate solutions. Am. Mineral. 75, 209-220.

Stoffregen, R.E., Rye, R.O., Wasserman, M.D., 1994. Experimental studies of alunite. II: ${ }^{18} \mathrm{O}-{ }^{16} \mathrm{O}$ and $\mathrm{D}-\mathrm{H}$ fractionation factors between alunite and water at $250-450{ }^{\circ} \mathrm{C}$. Geochim. Cosmochim. Acta 58, 903-916.

Stoffregen, R.E., Alpers, C.N., Jambor, J.L., 2000. Alunite-jarosite crystallography, thermodynamics, and geochronology. In: Alpers, C.N., Jambor, J.L., Nordstrom, D.K. (Eds.), Sulfate Minerals-Crystallography, Geochemistry, and Environmental Significance, Rev. Mineral. Geochem., vol. 40, pp. 454-479.

Tassinari, C.C.G., Macambira, M.J.B., 1999. Geochronological provinces of the Amazonian Craton. Episodes 22, 174-182.

Taylor, H.P., 1968. The oxygen isotope geochemistry of igneous rocks. Contrib. Mineral. Petrol. 19, 1-71.

Thompson, J.F.H., Lessman, J., Thompson, A.J.B., 1986. The Temora gold-silver deposit: a newly recognized style of high sulfur mineralization in the Lower Paleozoic of Australia. Econ. Geol. 81, 732-738.

Vasquez, M.L., Klein, E.L., 2000. Geologia e recursos minerais da Folha Rio Novo (SB.21-Z-C). Estado do Pará, Escala 1:250.000. PROMIM Tapajós, CPRM, Brasília, Brazil (CD-ROM).

Wasserman, M.D., Rye, R.O., Bethke, P.M., Arribas Jr., A., 1992. Methods for separation and total stable isotope analysis of alunite. Open-File Rep. (U. S. Geol. Surv.), 92-99.

Whelan, J.F., Rye, R.O., DeLorraine, W., 1984. The BalmatEdwards zinc-lead deposit-synsedimentary ore from Mississippi Valley-type fluids. Econ. Geol. 79, 239-265. 